\title{
QUEEN'S
UNIVERSITY
BELFAST
}

\section{Stone temperature and moisture variability under temperate environmental conditions: implications for sandstone weathering}

McAllister, D., Warke, P., \& McCabe, S. (2016). Stone temperature and moisture variability under temperate environmental conditions: implications for sandstone weathering. Geomorphology.

https://doi.org/10.1016/j.geomorph.2016.12.010

\section{Published in:}

Geomorphology

\section{Document Version:}

Peer reviewed version

Queen's University Belfast - Research Portal:

Link to publication record in Queen's University Belfast Research Portal

\author{
Publisher rights \\ (C) 2016 Elsevier. \\ This manuscript is distributed under a Creative Commons Attribution-NonCommercial-NoDerivs License \\ (https://creativecommons.org/licenses/by-nc-nd/4.0/), which permits distribution and reproduction for non-commercial purposes, provided the \\ author and source are cited.
}

\section{General rights}

Copyright for the publications made accessible via the Queen's University Belfast Research Portal is retained by the author(s) and / or other copyright owners and it is a condition of accessing these publications that users recognise and abide by the legal requirements associated with these rights.

Take down policy

The Research Portal is Queen's institutional repository that provides access to Queen's research output. Every effort has been made to ensure that content in the Research Portal does not infringe any person's rights, or applicable UK laws. If you discover content in the Research Portal that you believe breaches copyright or violates any law, please contact openaccess@qub.ac.uk. 
1 Stone temperature and moisture variability under temperate

2 environmental conditions: implications for sandstone weathering

3

4 Daniel McAllister ${ }^{1}$, Patricia Warke ${ }^{2 *}$ \& Stephen McCabe ${ }^{3}$

5

6

$7{ }^{1}$ The Dow Chemical Company - Belfast, Northern Science Park, Belfast BT3 9DT,

8 United Kingdom,

$9 \quad{ }^{2}$ School of Natural \& Built Environment, Queen's University Belfast, Belfast BT7

10 1NN, United Kingdom

$11{ }^{3}$ Northern Ireland Environment Link, 89 Loopland Drive Belfast BT6 9DW, United

12 Kingdom

13

$14{ }^{*}$ Corresponding Author: Patricia Warke - p.warke@qub.ac.uk 


\section{Abstract}

2 Temperature and moisture conditions are key drivers of stone weathering processes

3 in both natural and built environments. Given their importance in the breakdown of

4 stone, a detailed understanding of their temporal and spatial variability is central to

5 understanding present-day weathering behaviour and for predicting how climate

6 change may influence the nature and rates of future stone decay.

7 Subsurface temperature and moisture data are reported from quarry fresh Peakmoor

8 Sandstone samples exposed during summer (June-July) and late autumn / early

9 winter (October-December) in a mid-latitude, temperate maritime environment.

10 These data demonstrate that the subsurface thermal response of sandstone

11 comprises numerous short-term (minutes), low magnitude fluctuations superimposed

12 upon larger-scale diurnal heating and cooling cycles with distinct aspect-related

13 differences. The short-term fluctuations create conditions in the outer $5-10 \mathrm{~mm}$ of

14 stone that are much more 'energetic' in comparison to the more subdued thermal

15 cycling that occurs deeper within the sandstone samples.

16 Data show that moisture dynamics are equally complex with a near-surface region

17 (5-10 mm) in which frequent moisture cycling takes place and this, combined with

18 the thermal dynamism exhibited by the same region may have significant implications

19 for the nature and rate of weathering activity. Data indicate that moisture input from

20 rainfall, particularly when it is wind-driven, can travel deep into the stone where it can

21 prolong the time of wetness. This most often occurs during wetter winter months

22 when moisture input is high and evaporative loss is low but can happen at any time

23 during the year when the hydraulic connection between near-surface and deeper

24 regions of the stone is disrupted with subsequent loss of moisture from depth slowing

25 as it becomes reliant on vapour diffusion alone. 
1 These data illustrate the complexity of temperature and moisture conditions in 2 sandstone exposed to the 'moderate' conditions of a temperate maritime 3 environment. They highlight differences in thermal and moisture cycling between 4 near-surface $(5-10 \mathrm{~mm})$ and deeper regions within the stone and contribute towards 5 a better understanding of the development of structural and mineralogical 6 heterogeneity between the stone surface and substrate.

7 Keywords: Peakmoor sandstone; temperature; moisture; weathering 


\section{$1 \quad 1.0 \quad$ INTRODUCTION}

2 Temperature and moisture are key drivers of sandstone weathering processes in

3 both natural and built environments. The temperature of stone is a major factor in

4 determining the rate and direction of energy and moisture transfer and its exchanges

5 with the atmosphere (c.f. Hillel 1998). Temperature also governs the nature and

6 intensity of the chemical, physical and biological weathering processes that

7 contribute to the decay and modification of sandstone by controlling the rates and

8 frequency of their operation. The presence of moisture is central to the effective

9 operation of the majority of mechanisms driving stone decay and understanding its

10 mobility within stone and how this varies over space and time is essential.

11 However, current understanding of stone temperature characteristics under natural

12 conditions of exposure is considerably more developed than that for moisture content

13 principally because temperature is recognised as generally being easier to measure

14 (McGreevy and Whalley 1987; Hall and André 2001). Consequently, it is not

15 surprising that there exists an extensive literature documenting thermal observations

16 of stone and monitoring programmes conducted in a wide array of geographical

17 settings (see Table 1 for examples).

18 These studies have had a tendency to highlight temperature maxima/minima and

19 'typical' diurnal regimes, with more recent studies placing emphasis on spatial and

20 temporal thermal variability at decreasing scales of enquiry (e.g. Gómez-Heras et al.

21 2006; Hall 1997; Hall and André 2001, 2003; Jenkins and Smith 1990; Smith 2009).

22 But, what is of more concern is the fact that many of these geomorphologically

23 focussed observations have largely concentrated on thermal conditions experienced

24 in the more 'extreme' climatic locations such as hot and cold deserts and high 
1 altitude environments - typically driven by the ongoing debate over the role of

2 insolation weathering in the breakdown of stone (McFadden et al, 2005).

3 Although such observations have undoubtedly helped to shape the design of 4 laboratory weathering simulation experiments, it is important to remember that 5 arguably, they represent the extreme ends of the climatic spectrum. Consequently, 6 more may be known about stone temperature conditions in 'extreme' environments 7 than more temperate conditions thereby resulting in an understanding based on a 8 rather skewed dataset.

9 Because the presence of moisture is central to the effective operation of the majority 10 of mechanisms initiating and driving stone breakdown, understanding its dwell time 11 and mobility within stone is essential. However, much of our current understanding is 12 based on assumption rather than empirical evidence primarily because of the difficulty of collecting accurate data over meaningful time periods especially in fieldbased settings. The key problems associated with measuring subsurface moisture content of stone using technologies such as capacitance humidity sensors, resistivity probes and electrical resistivity tomography, is a low level of sensitivity to change especially under conditions of saturation, measurements that can be influenced by 18 the ionic content of the moisture and the potential for sensor drift from an initial calibrated state (for examples of use see; Srinivasan et al, 2010; Smith et al, 2011; McAlister et al 2011; Sass and Viles 2010a and 2010b; Sass 2003; Stojanovič et al, 21 2010). In addition, the very act of drilling into stone for positioning of moisture 22 sensors can create conduits for preferential moisture flow and accumulation. 23 Although, in comparison to the collection of thermal data, the collection of reliable 24 stone moisture data remains challenging, in recent years the situation has started to 25 improve with technological developments in moisture measurement associated with 
1 research being undertaken in the soil and medical sciences (Hall 2007; Sass 2005;

2 Pel and Huinink 2009).

3 Temperature and moisture conditions within stone are closely interconnected, with

4 change in one resulting in alteration of the other. Their role in stone weathering is 5 pivotal but the extent and potential complexity of their temporal and spatial variability

6 in temperate environments is not fully recognised and hence not fully understood.

7 This study, and the data reported, seeks to redress this situation with an investigative 8 focus on the following two areas:

1. Identifying temperature characteristics of sandstone samples exposed in a sandstone in response to changing meteorological conditions.

14 These data provide the basis for questions about the potential effectiveness of weathering processes in temperate environments and the complexity of thermal and moisture response characteristics in the outer few millimetres of stone and conditions

17 in deeper substrate regions.

\subsection{MATERIALS AND METHODS}

20 Temperature and moisture data were collected from Peakmoor Sandstone samples 21 in an outdoor test facility in Belfast, Northern Ireland. Detail of the sandstone, the 22 field site and data collection methods is given in the following sections. 


\section{$1 \quad 2.1 \quad$ Material Properties}

2 Peakmoor Sandstone is a buff-coloured, quartz-rich, fine to medium grained

3 Millstone Grit of Carboniferous age (350-300 Ma) with a relatively homogenous

4 structure in which, for the most part, obvious bedding and micro-lamination structures

5 are absent. A summary of material properties and pore size distribution as

6 determined by Mercury Intrusion Porosimetry (MIP) are shown in Table 2 and Figure

7 1, respectively. Mineralogy and porosity properties are important because of their

8 role in determining the thermal properties of stone and its ability to absorb moisture,

9 transfer it to deeper substrate layers and restrict its loss through evaporation.

\section{$\begin{array}{lll}11 & 2.2 & \text { Field Site }\end{array}$}

12 Northern Ireland is located at approximately $55^{\circ} \mathrm{N} 6^{\circ} \mathrm{W}$ (Figure 2) and because of this

13 mid-latitude location and its position on the edge of the North Atlantic is subject to

14 temperate maritime climatic conditions where extremes of temperature are rare because of the ameliorating effect of the North Atlantic and the Gulf Stream (Betts 1997). The prevailing direction of incoming weather systems is from the southwest

17 with the flow typically dominated by the passage of low pressure (cyclonic) systems

18 usually of 2-3 days duration interspersed by high pressure (anticyclonic) conditions

19 of varying intensities which, when strongly established can sometimes persist for a 20 week or more.

21 While the average meteorological values shown in Table 3 mask the extremes that 22 can occur (see McAlister et al, 2013), they demonstrate the 'moderate' nature of 23 conditions that dominate in this mid-latitude location. 


\section{$1 \quad 2.3 \quad$ Experimental Set-up and Data Collection}

2 The test unit assembly was securely sited in the city of Belfast. It was constructed

3 using a galvanised steel frame into which plywood sheets were set with a wooden lid

4 that enclosed the interior where the data-loggers were located (Figure 3).

5 The 'quarry fresh' Peakmoor sandstone was cut into blocks (200 mm length X 100

$6 \mathrm{~mm}$ width $\mathrm{X} 200 \mathrm{~mm}$ depth). Four sides of each block were sealed with a coating of

7 varnish and placed in a $20 \mathrm{~mm}$ thick 'jacket' of expanded polystyrene. This was done

8 to insulate the blocks and to limit heat and moisture exchange with the external

9 environment to just the outer exposed face of each block. This method has been

10 used in previous studies (e.g. Smith et al, 2008; Smith et al, 2011) and has the effect

11 of enabling smaller blocks to mimic the response characteristics of larger pieces of

12 stone. Following preparation, each block was placed into pre-cut slots in the plywood

13 sides of the test unit.

14 The test structure was orientated to ensure that the blocks faced northeast (NE), 15 southeast (SE), southwest (SW) and northwest (NW) thereby enabling the 16 identification of aspect-related differences in thermal and moisture characteristics 17 (Figure 3).

\subsubsection{Monitoring meteorological conditions}

20 A Davis Vantage Pro II weather station was located several meters from the test unit

21 with weather data recorded at one-minute intervals. Simultaneous meteorological 22 data allows meaningful comparison with, and interpretation of, sandstone response 23 to changing external conditions. 


\section{$1 \quad$ 2.3.2 Temperature data collection}

2 Collecting stone surface temperature measurements can be problematic as generally

3 the process involves the use of thermistors, thermocouples, micro-electro-

4 mechanical sensors (MEMS) or iButtons in direct contact with the stone. As such,

5 their very presence may alter stone surface temperature through shielding effects

6 such that the recorded temperatures may represent heat conducted from the

7 surrounding material and negate the effect of radiative heating (Warke 2000), or that

8 the recorded temperature may reflect the sensor response to radiation more than that

9 of the stone surface itself. Attempts have been made to address such issues through

10 the use of non-contact infrared devices but although this may be applicable for

11 collection of surface temperature data, the collection of subsurface data is

12 constrained by current technology and can only be done using direct contact

13 methods.

14 Because of the problems associated with surface temperature recording, on site

15 stone surface temperature was not measured in this study with the emphasis instead

16 on near-surface and deeper thermal response of the sandstone blocks.

17 Consequently, temperature sensors were positioned at depths of 5, 10, 20, 50 and

$18100 \mathrm{~mm}$ from the exposed block surfaces (Figures $4 \mathrm{a}$ and $4 \mathrm{c}$ ). The sensors used at

19 this site were $5 \mathrm{kohm}$ NTC thermistors with a bead diameter of $2.4 \mathrm{~mm}$, a response

20 time of 15 seconds and an accuracy of $\pm 1 \%$.

21 The sensors were inserted into $6 \mathrm{~mm}$ wide pre-drilled holes at the rear of the blocks

22 which were then back-filled with powdered stone and plugged with mastic adhesive

23 (Figure 4b). Data were recorded at intervals of five minutes during the summer 24 months (June and July) and at intervals of one minute during the October to

25 December recording period. This difference in data recording intervals reflects some 
1 unavoidable technical issues but the resultant data still provide a robust record of

2 thermal response of the Peakmoor sandstone samples.

\subsubsection{Moisture data collection}

5 A variety of direct and indirect stone moisture measurement methods exist and can 6 vary widely in reliability, ease of use and accuracy (Hall and Hoff 2002). Data

7 reported here were collected using custom-made 2-pin resistivity probes. As with the 8 temperature sensors, the moisture measurement probes were inserted into separate 9 pre-drilled holes to depths of 5, 10, 20, 50 and $100 \mathrm{~mm}$ from the exposed block surfaces (Figures $4 a-c)$.

11 Resistivity probes provide an indirect method of moisture measurement that relies on

12 varying dielectric properties of the stone with changing moisture content. The 13 resistivity value or Resistance Ratio (RR) provides a 'measure' of moisture content with decreasing values indicative of wetter conditions and vice versa. This method is particularly useful for monitoring change in conditions over time and offers a relatively high level of precision (e.g. Srinivasan et al, 2010; Smith et al, 2008, 2011). However,

17 this method is not perfect as sensitivity can decrease under saturated conditions and 18 measurements may be influenced by ionic content of moisture although the latter should be less problematic in this instance because 'quarry fresh' stone was used and therefore free ion content within the samples was minimal.

21 These methods of moisture and temperature data collection, by their intrusive nature, may provide an approximation of the actual internal conditions of the stone but it is 23 not possible, given current technology, to calculate the effects of the methods of data 24 collection used on the precision of the resultant data. We can infer that the aspect 
1 and depth related differences in temperature and moisture results reported in the

2 following sections indicate that the sensors within the stone samples are sufficiently

3 accurate to reflect differences in the receipt of direct insolation and moisture input

4 from directional rainfall and that the near-surface temperatures are in line with the

5 external air temperatures.

6

\section{$7 \quad 3.0 \quad$ RESULTS AND INTERPRETATION}

8 Temperature and moisture data are reported separately in the following sections but

9 because of the quantity of material collected only selected representative sections of

10 the total dataset are presented.

\subsection{Overview of Temperature Data}

13 Internal stone temperatures collected at depths of 5, 10, 20, 50 and $100 \mathrm{~mm}$ below

14 block surfaces for June-July and September-December monitoring periods are

15 presented in Figures $5 \mathrm{a}$ and $5 \mathrm{~b}$, respectively. Because of the quantity of data collected the focus here is on the response of the NE and SW facing test blocks as

17 being representative of the greatest differences in direct input of solar radiation with

18 the SW facing block experiencing the greatest potential for receipt of solar energy

19 while the NE facing block had the least.

20 The temperature characteristics of each depth from these two aspects are 21 summarised in Tables $4 \mathrm{a}$ and $4 \mathrm{~b}$ for the June-July and September-December 22 monitoring periods, respectively. Despite differences related to aspect, which will be 23 discussed later, the 'pattern' of stone temperature response is broadly similar with 24 temperature conditions reflecting diurnal heating and cooling cycles with the 
1 amplitude of these cycles increasing and decreasing in response to the passage of 2 synoptic weather systems.

3 The difference between daily stone temperature highs and lows varies considerably

4 from around $2^{\circ} \mathrm{C}$ to $22^{\circ} \mathrm{C}$ for example, between weeks 5-7 (June-July period). The 5 diurnal temperature difference at $5 \mathrm{~mm}$ depth in the SW facing block during summer 6 (Figure $5 \mathrm{a}$ ) ranged from $2-3^{\circ} \mathrm{C}$ during a period of low pressure cyclonic conditions 7 with the associated cloud cover; following this, high pressure brought clear sky 8 conditions producing a diurnal temperature range of around $22^{\circ} \mathrm{C}$.

9 The anticyclonic conditions that developed towards the end of July were associated with the recorded subsurface stone temperature maxima (Table 4a). As expected, 11 these values were highest at $5 \mathrm{~mm}$ below the block surface, with temperatures of $1226.7^{\circ} \mathrm{C}$ and $34.6^{\circ} \mathrm{C}$ being experienced in the NE and SW facing blocks, respectively. 13 These stone temperatures exceed the highest air temperature of $23.5^{\circ} \mathrm{C}$ recorded during the same monitoring period. During the June-July monitoring period stone temperature maxima were lowest at $100 \mathrm{~mm}$ depth and stone temperature minima were relatively similar at all depths and across all aspects, ranging from $5.7-6.4^{\circ} \mathrm{C}$ 17 (Table 4a).

18 During the September-December recording period, stone temperature maxima (at all depths) were again highest in the SW facing block. Stone temperature maxima at 5 $\mathrm{mm}$ depth were $17.0^{\circ} \mathrm{C}$ and $23.0^{\circ} \mathrm{C}$ for the $\mathrm{NE}$ and SW blocks, respectively; the maximum air temperature recorded was $17.0{ }^{\circ} \mathrm{C}$ while the maximum temperatures experienced at 50 and $100 \mathrm{~mm}$ depth were slightly lower than this value (Table $4 \mathrm{~b}$ ).

23 During this monitoring period stone temperature minima reached $-2.5^{\circ} \mathrm{C}$. The results presented highlight aspect- and depth-related temperature differences. 


\section{$1 \quad 3.1 .1$ Aspect-Related Temperature Fluctuations}

2 Figure 6a (Inset 1) shows stone temperature data at $5 \mathrm{~mm}$ below the stone surface

3 for a cloudy summer day in July in which stone temperatures present a 'dampened'

4 diurnal range relative to the rest of the two-week time series and particularly in 5 comparison to temperature response to 'clear sky' conditions (Figure 6b).

6 Under cloudy conditions aspect-related differences are minimised producing similar

7 thermal responses and a depressed diurnal regime which, on the cloudy day was 8 reduced to $5.5-6.0^{\circ} \mathrm{C}$.

9 Stone temperatures throughout the day exhibit a sinusoidal distribution (c.f. GómezHeras et al. 2008), which, combined with the consistency between aspects (differing

11 by no more than $0.2^{\circ} \mathrm{C}$ ) suggests the dominance of convective heating throughout

12 the day through the direct transfer of heat energy from the air in contact with block

13 surfaces into the stone. As shown in Figure 6a, low levels of radiation were recorded 14 with a daily maximum of $323 \mathrm{~W} / \mathrm{m}^{2}$.

15 Figure $6 b$ presents the same variables for a day characterised by 'clear sky' 16 conditions when stone temperature conditions were markedly different with a 17 pronounced aspect-related variability evident throughout the day. Air temperatures 18 exhibited a diurnal range of $8.3^{\circ} \mathrm{C}$; while stone temperatures at $5 \mathrm{~mm}$ depth in the NE and SW facing blocks produced temperatures of $11.5^{\circ} \mathrm{C}$ and $20.1^{\circ} \mathrm{C}$, respectively.

20 The maximum air temperature was $22.2^{\circ} \mathrm{C}$ whereas stone temperature maxima were $2125.7^{\circ} \mathrm{C}$ and $34.5^{\circ} \mathrm{C}$ for the NE and SW blocks, respectively. The timing of stone 22 temperature maxima for each aspect and the curves of daily distributions of 23 temperature identify two overlapping heating regimes - convective and radiative 24 heating (with the latter occurring when stones are in direct receipt of solar radiation). 
1 Before sunrise, subsurface stone temperatures were consistent across all aspects 2 decreasing close to the ambient air temperature, reflecting heat flux to the

3 atmosphere and establishment of relative equilibrium between the air temperature 4 and the outer few centimetres of stone (Figure 6b, Inset 2). Following sunrise, at 5 05:00 hours, temperatures at $5 \mathrm{~mm}$ depth in the NE facing block increased rapidly 6 (from $14.4^{\circ} \mathrm{C}$ to $20.3^{\circ} \mathrm{C}$ over a one hour period). Meanwhile stone temperatures in the 7 other aspects showed values of between $14.6^{\circ} \mathrm{C}$ and $15.2^{\circ} \mathrm{C}$. During this period the 8 temperature distribution in the NE facing block showed a radiative pattern of heating 9 that coincided with an increase in total solar radiation. At around 11.00 hours the 10 temperature distribution in the NE facing block appeared to change to a sinusoidal 11 pattern that reflected it being thrown into shade as the sun tracked through the sky 12 with convective processes largely controlling heat transfer between air and stone.

13 Radiative heating was experienced next in the SE, then the SW and finally in the NW 14 facing blocks, reflected again by increasing stone temperatures to values 15 considerably higher than ambient air temperatures. The SW facing block appeared to 16 receive the most irradiance, and was over $10^{\circ} \mathrm{C}$ warmer than air temperatures 17 recorded at the same time demonstrating the importance of radiative heating processes on stone thermal regimes.

19 When direct receipt of solar radiation ceases, or is interrupted by, for example, the 20 passage of clouds, such as that shown by the SW facing sample at around 19.00 21 hours, or by shading related to structural influences (nearby buildings), such as that 22 which occurs around 07.30 hours affecting the NE facing block, stone temperatures 23 experienced an exponential decrease (c.f. Gómez-Heras et al. 2008).

24 Stone temperatures at $5 \mathrm{~mm}$ depth and air temperatures are presented for a three25 day period in November (Figures $7 \mathrm{a}$ and $7 \mathrm{~b}$ ) to illustrate the role of convective and 
1 radiative heating regimes. Because of the changing position of the sun in the sky

2 (that is the solar azimuth at times of sunrise and sunset) during winter only the SE

3 and SW aspect experience the overlapping of convective and radiative (through

4 direct insolation) heating regimes. Clear sky conditions persisted throughout the $21^{\text {st }}$

5 November, as evidenced by the 'bell-curve' distribution of total radiation (Figure 7b),

6 and stone temperatures at $5 \mathrm{~mm}$ depth in the SE and SW facing samples,

7 respectively, were around $6^{\circ}$ and $8^{\circ} \mathrm{C}$ higher than air temperatures recorded at the

8 same time. These radiation data also indicate the reduced daylight hours during

9 winter.

10 During the period of sub-zero air temperature conditions experienced in December,

11 stone temperatures in the SW facing block remained above $0^{\circ} \mathrm{C}$ because of radiative

12 heating under clear sky conditions while stone temperatures at $5 \mathrm{~mm}$ below the

13 surface in the NE facing block remained below $0^{\circ} \mathrm{C}$. These data highlight the

14 significance of aspect in creating potentially favourable conditions for the operation of

15 different weathering processes.

\section{$17 \quad 3.1 .2$ Depth-Related Temperature Fluctuations}

18 Due to the quantity of material recorded, again only selected data from

19 measurements recorded in July at depth (5, 10, 20, 50 and $100 \mathrm{~mm})$ in the NE

20 (Figure 8a) and SW (Figure 8b) facing blocks are reported.

21 During the hours of darkness, the NE and SW facing block temperatures at each 22 depth converged to within $0.2^{\circ} \mathrm{C}$ of each other. During daytime solar heating depth23 related temperature variations widened, with differences of up to $4^{\circ} \mathrm{C}$ recorded 24 between 5 and $100 \mathrm{~mm}$ depth (Figure 8a, Inset 1). Not surprisingly, temperatures are 
1 more dynamic closer to the surface with temperatures at $5 \mathrm{~mm}$ depth exhibiting

2 higher values and more rapid rates of change than those at greater depth (Figure

3 8b). For example, following a period of cloud cover and reduction of incoming direct

4 insolation from around 17.40 hours (Figure $8 \mathrm{~b}$, Inset 1), temperatures at 5 and 10

$5 \mathrm{~mm}$ decreased first, whereas temperature decreases at 50 and $100 \mathrm{~mm}$ were slower

6 and more diffuse.

7 Differences occurred in the subsurface cooling response of the NE and SW facing

8 blocks. Data from the SW facing block collected in the summer recording period

9 (June-July) identified a 'cross-over' or reversal in thermal conditions between

10 different depths within the sandstone. At dusk as the effects of direct solar radiation

11 receipt declined the outer $5-50 \mathrm{~mm}$ of stone started to cool while deeper into the

12 block the $100 \mathrm{~mm}$ sensor indicated that this cooling was less pronounced with the

13 result that for several hours the thermal gradient established during the day in which

14 temperatures decreased from the outer layers of stone block to depth was reversed.

15 Hall et al. (2008a) reported the same feature, stating that it indicates that during the

16 warming phase near surface locations heat faster than at $100 \mathrm{~mm}$ depth, while during

17 the cooling phase near-surface locations lose heat more rapidly than at $100 \mathrm{~mm}$

18 depth. It is important to note that this trend was so clearly developed in the NE facing

19 sample reflecting the naturally lower receipt of direct solar radiation and the reliance

20 on convective heating.

\subsection{Overview of Moisture Data}

23 Resistivity sensors show that clear seasonal differences in moisture content exist for 24 all aspects with a peak during winter months followed by a decline during spring and 25 summer months to a minimum point in September. However, this seemingly simple 
1 long-term trend masks a much greater level of complexity in the shorter-term

2 reflecting changing inputs (typically rainfall) and outputs (evaporation). Consequently,

3 on a day-to-day basis within the longer-term trend, moisture content can be

4 extremely variable.

5 This variability is most clearly demonstrated through the mobility of the 'wetting front'

6 with its arrival identified by a rapid decrease in the Resistance Ratio (RR) indicated

7 by the moisture sensors. The term 'wetting front' is used to identify the boundary

8 between wet and dry or less wet stone. The rate of movement of the wetting front

9 reflects both intrinsic and extrinsic factors. The former include stone properties such

10 as porosity and pore connectivity, properties that determine the hydraulic conductivity

11 characteristics of stone. The latter include factors such as the intensity and duration

12 of rainfall events and input of additional energy from wind that helps to drive moisture

13 deeper into the stone fabric than it would otherwise have done under more calm

14 conditions.

15 Data collected during the monitoring period identified the presence of wetting fronts 16 across all aspects and at all monitored depths with the exception of the $100 \mathrm{~mm}$ 17 depth (Figure 9a-d). However, there are clear differences between different aspects 18 and the depth of the wetting front with, for example, the NW facing sample exhibiting 19 the lowest number of near-surface wetting events. Figure 9b shows that following 3 20 days of exposure a 'wetting front' was identified at a depth of $5 \mathrm{~mm}$ below the block 21 surface in the NE facing sample with the RR decreasing from 1.0 to 0.25 over a 22 period of 5 minutes in response to a rainfall event. The same 'wetting front' was 23 detected at depths of 10,20 and $50 \mathrm{~mm}$ after another 70,125 and 515 minutes, 24 respectively (Table 5). 
1 As shown in Table 5, the progress of the wetting front differs depending on aspect

2 and the severity of the rainfall event. For example, the rainfall hitting the NE facing

3 block on the $12^{\text {th }}$ June and $7^{\text {th }}$ July takes similar times for the respective wetting

4 fronts to reach depths of 10 and $20 \mathrm{~mm}$. However, the wetting front does not reach a

5 depth of $50 \mathrm{~mm}$ on the $7^{\text {th }}$ July, presumably reflecting differences in the duration and

6 intensity of the rainfall event and the amount of incident moisture.

7 Data indicate that the coincidence of rain, the presence of wind and high ambient 8 humidity levels ( $>90 \%$ ) combine to produce conditions that promote the rate of travel 9 and penetration of the wetting front. For example, in comparison to the rainfall event 10 of the $7^{\text {th }}$ July, greater wind-speed $\left(>14 \mathrm{~m} \mathrm{~s}^{-1}\right)$, antecedent rainfall amounts and 11 greater duration of the rainfall event on the $12^{\text {th }}$ June explain why the wetting front 12 reached a depth of $50 \mathrm{~mm}$ on this date (Figure 10). Wind-driven rain is widely 13 identified as a means of facilitating deep moisture penetration into porous material 14 (e.g. Blocken and Carmeliet 2004; Briggen et al, 2009) such as the Peakmoor 15 Sandstone used in this study. It is noted that wind impacting a porous surface can 16 create pressure differentials of up to $3 \mathrm{hPa}$ across the stone surface, conditions that 17 encourage the inward movement of moisture (Camuffo 1995; Beall 1998; Pérez-Bella 18 et al, 2013).

19 In addition to the wetting of stone, the resistivity sensors also recorded drying 20 dynamics at various depths. These data clearly show that moisture cycling occurs to 21 depths of at least $50 \mathrm{~mm}$ under temperate conditions and highlight the distinction 22 between the rates at which wetting and drying processes can occur, particularly the 23 length of time drying takes deeper into the stone and the persistence of this deeper 24 moisture. 
1 In general the drying of stone takes more time that the wetting of stone. For example,

2 following the wetting of stone during the rainfall event on the $12^{\text {th }}$ June, the wetting

3 front in the NE facing sample took more than 1 hour to reach a depth of $10 \mathrm{~mm}$ but it

4 took more than 200 hours for the same sensor to achieve a RR of 1.0 which is

5 indicative of dry stone. Accepting that there may be some discrepancy between

6 moisture conditions in close proximity to the sensor and further away from it in terms

7 of the rate of drying, data indicate that drying is a much more energy intensive

8 process with the same capillary forces that help draw moisture into stone and that

9 control its subsequent movement deeper into the substrate also acting to retain

10 moisture and prevent its evaporative loss.

11 Data indicate the existence of a spatial imbalance in the effectiveness of drying 12 between the stone surface and substrate. For example, on the $12^{\text {th }}$ June the NE 13 block sensors indicated that the stone surface dried first with the sensor at $5 \mathrm{~mm}$ 14 depth registering 'dry' conditions (RR of 1.0) after 176 hours and the sensors at 10 15 and $20 \mathrm{~mm}$ depth achieving the same condition after 201 and 366 hours, 16 respectively. Drying, like wetting, occurs first at the stone surface and is controlled by 17 both surface and air temperature conditions along with airflow, which facilitates evaporative loss. Consequently, surface moisture content decreases resulting in an 19 exponential decrease in liquid hydraulic diffusivity (Hillel 1998).

20 This situation continues until a critical level of moisture content is reached that marks

21 the change between capillary and vapour transport processes. At this point the 22 moisture link between surface and substrate is disrupted with the result that the 23 drying front recedes deeper into the stone leaving vapour diffusion as the only 24 effective transport mechanism through which moisture held at depth can escape. As 
1 a consequence of the greater energy required to maintain the operation of this

2 mechanism, the rate of drying slows.

3 Identification of the dynamics of drying are complicated by subsequent wetting 4 events as demonstrated in Figure 11 where sensors at depths of 20 and $50 \mathrm{~mm}$ 5 show increasing $R R$ values (indicative of drying) while at the same time the sensors 6 at 5 and $10 \mathrm{~mm}$ exhibit more complex fluctuations between wet and dry conditions in 7 response to separate rainfall events on the $20^{\text {th }}, 24^{\text {th }}$ and $25^{\text {th }}$ July.

8 In terms of stone weathering, these data highlight the greater potential for weathering

9 activity related to the greater frequency of transitions between wet and dry conditions 10 and hence time of wetness in the outer few millimetres of stone and support the 11 identification by McCabe et al, (2015) of the development over time of within block 12 heterogeneity where previously none existed.

$14 \quad 4.0 \quad$ Implications for Sandstone Weathering in 'Temperate' Environments

15 The significance of data reported here lies not so much in the actual observed 16 values, although these are of importance in demonstrating the potential range of 17 conditions stone in a 'temperate' environment can be exposed to, rather these 18 temperature and moisture data provide an indication of the ever-changing and 19 complex conditions experienced by stone over various time-scales. Frequent 20 transitions from wet to dry and warm to cold conditions (and vice versa) and the 21 associated energy exchanges create the potential for the operation of a variety of 22 weathering mechanisms. These data indicate that this potential for weathering is 23 greatest in the outer few millimetres of stone where temperature and moisture 24 conditions are especially dynamic but they also point to the complexity of 
1 temperature and moisture cycling between the near-surface and deeper sandstone 2 substrate.

\section{$4 \quad 4.1 \quad$ Thermal Heterogeneity}

5 Temperature data identified thermal responses characterised by heterogeneity with 6 near-surface stone (c.5-10 mm) exhibiting frequent (order of minutes and probably 7 less) but relatively low magnitude fluctuations in temperature response directly driven 8 by environmental conditions (e.g., shade, passage of cloud, increase in wind-speed).

9 In comparison, at the same time deeper within the stone thermal response appears to follow a much less 'energetic' regime being more closely linked to the diurnal scale

11 of environmental heating and cooling cycles. This reflects the typically poor thermal 12 conductivity properties of stone and the time required to transfer thermal energy 13 received at the surface to deeper substrate areas - a response time that exceeds the duration of the near-surface short-term temperature fluctuations thereby preventing their expression.

In particular, the more 'energetic' character of heating and cooling fluctuations in the

17 outer $5-10 \mathrm{~mm}$ of stone (temperature range $1-2^{\circ} \mathrm{C}$ ) repeated day after day may 18 contribute to the development of the physically expressed heterogeneity between 19 surface and substrate described by McCabe et al, (2015) by creating conditions conducive to greater moisture flux (wetting and drying) with mobilisation and

21 precipitation of salts and other contaminants. In addition, the ability of natural cycles 22 of short-term (a minute or less) temperature change operating over a shallow, near23 surface region to generate a sufficient shock to fracture stone has been identified by 24 other researchers (e.g., Hall 1999; Hall and André 2001, 2003; Gómez-Heras et al. 2006, 2008; Smith 2009, 2012) with the critical value for this shock often cited to be a 
1 temperature change of $2{ }^{\circ} \mathrm{C} /$ minute (Richter and Simmons 1974; Yatsu 1988). The

2 frequency of occurrence of such temperature changes has been found, through high-

3 resolution thermal monitoring studies, to be greater than previously thought (Hall and

4 André 2001; Gómez-Heras et al. 2006; McKay et al. 2009; Molaro and McKay 2010)

5 and data reported here tends to support these findings in a temperate environmental

6 setting.

7 Despite the debate that continues over the role of insolation-related weathering in the

8 breakdown of stone, technological developments now allow researchers to more

9 accurately quantify the effects of heating and cooling on stone. This is demonstrated

10 by Collins and Stock (2016) who showed that exposure to repeated thermal cycles

11 created cumulative deformation capable of fracturing exfoliating sheets of granite.

12 Although they focus on a different lithology to that reported here, their work highlights

13 the significance of repeated thermal cycling and its role in the weakening of stone.

14 With regard to the role of thermal response in establishing the condition of thermal

15 heterogeneity, aspect-related differences in the nature of heating regimes (ie; the

16 relative inputs of radiative versus convective heating) may contribute to the degree of

17 heterogeneity that develops (Figure 12). For example, data reported here indicate

18 that those aspects exposed to a greater amount of radiative heating exhibit more

19 'energetic' thermal response characteristics in the outer few millimetres of stone and

20 it is suggested that, overtime, the rate and extent of the development of emerging

21 heterogeneity in such aspects would be greater. This in turn may have significant

22 implications for differences in the efficacy of weathering processes, their depth of

23 penetration into stone and the subsequent rate of deterioration.

24 This thermal heterogeneity is similar to the physical heterogeneity identified by 25 McCabe et al, (2015) in that it demonstrates spatially variable properties. However, 
1 whereas the emerging heterogeneity identified by McCabe at al, (2015) reflects the

2 effect of spatially variable physical properties within stone such as porosity and

3 permeability, the establishment of thermal heterogeneity is linked primarily to the

4 effects of aspect and the resulting differences in externally derived receipt of radiative

5 (as opposed to convective) heating during daylight hours. Consequently, thermal

6 heterogeneity is an ephemeral characteristic breaking down during the hours of

7 darkness when the effect of radiative heating is removed and the effect of aspect is

8 lost as convective heat exchange dominates.

9 It is important to note that data reported here represent the response of 'quarry fresh'

10 stone in which any weathering-related physical heterogeneity between surface/near-

11 surface and deeper substrate material has not had time to develop. Consequently,

12 we can only speculate as to whether the thermal response of aged stone would be

13 similar or whether the physical change in the outer few millimetres of stone would

14 result in the development, during daylight hours, of an increased or decreased

15 thermal heterogeneity.

16 The $5 \mathrm{~mm}$ boundary identified here is determined by the location of the temperature 17 sensors and should therefore be viewed as an indicator and not a definitive 18 measurement of boundary position. It is probable that the boundary between the 19 more energetic conditions in the outer few millimetres of stone and the more 20 'organised' and predictable conditions in the deeper substrate is transitional, 21 changing in response to factors such as energy conditions incident at the stone 22 surface, time of day and time of year.

\section{$24 \quad 4.2 \quad$ Moisture Dynamics and Weathering Implications}


1 It is widely recognised that temperature exercises a critical control on the occurrence

2 and severity of stone decay and the efficacy of weathering processes that cause it

3 (Hall et al. 2012). But temperature is not only important because of the stresses it

4 may induce through differential heating, it also exerts an influence on, and operates

5 in conjunction with, other factors to breakdown stone (Gómez-Heras et al, 2006). In

6 particular, its impact on moisture availability and movement, including evaporative

7 processes which are directly dependent on temperature conditions (Gómez-Heras et

$8 \quad$ al, 2006; Turkington et al, 2002).

9 It is this impact on moisture dynamics that may have the greatest implications for 10 weathering in temperate environments. In particular, the aspect-related differences in 11 the observed temperature values presented here may have implications for 12 disruption of 'hydraulic continuity' between stone surface/near-surface regions and 13 the deeper substrate of wet stone. This situation could arise when rapid temperature 14 cycling driving evaporative drying in the surface and near-surface zone results in a 15 progressive reduction in surface moisture content disrupting the hydraulic pathways 16 and hence continuity between the surface and depth resulting in the drying front 17 receding to a subsurface position. Such disruption will then necessitate the subsequent loss of moisture from depth to occur by vapour diffusion, which is a less effective mechanism of moisture movement. In a temperate environmental setting, reduction in the effective movement of moisture from deep within stone to the surface 21 may contribute to the establishment of a longer time of deep wetness of stone 22 particularly during winter months when the frequency and often the intensity of 23 moisture inputs are greater (McCabe et al, 2013; Shokri and Or, 2011; McAlister et 24 al, 2016). 
1 The physical effect of prolonged deep wetting of stone is not yet fully understood but

2 through the process of ion diffusion it may initially facilitate the movement of salts and

3 other contaminants deep into the fabric of stone where, following a sufficient

4 accumulation, under anaerobic conditions chemical weathering through prolonged

5 exposure to alkaline pore water may contribute to the destabilisation of silicate

6 minerals (McCabe et al, 2010). While the effect of such changes to the substrate will

7 not be immediately felt they may create weaknesses that will eventually gain surface

8 expression as the existing stone surface weathers back. It seems reasonable to

9 assume that any such deep-seated degradation of stone will be spatially variable

10 reflecting differences in such factors as pore connectivity and micro-structural

11 features, which facilitate the passage of moisture in some parts of stone and restrict it

12 elsewhere.

13 Such an influence on moisture flux will by association also influence the location and

14 kinetics of salt crystallisation within pores (Rodriguez-Navarro and Doehne 1999),

15 given that increasing temperatures can promote the precipitation of salts, and

16 decreasing temperatures can encourage salts to dissolve (Camuffo 1998; Smith et al.

17 2011). Moreover, upon heating, salts that have crystallised within pores typically

18 experience volume increases greater than that of most stone-forming minerals

19 (Goudie and Viles 1997; Smith 2012). The thermal heterogeneity described in the

20 previous section highlights how spatially and temporally variable temperature

21 conditions may control the depth of penetration and mobility of contaminants such as

22 salt that are carried by moisture. Data reported here show that the SW facing block

23 experienced the greatest number of wetting and drying cycles at depths of 5, 10, 20

24 and $50 \mathrm{~mm}$ reflecting both the greater incidence of rainfall because of the prevailing 
1 direction of weather systems and the greater potential for direct receipt of solar

2 radiation in comparison to other aspects.

3 As mentioned previously, temperature plays a fundamental role in the freezing of 4 water within pores. This occurs at varying sub- $0^{\circ} \mathrm{C}$ temperatures (depending on, for 5 example, pore size and water chemistry) and is thought, to act, through several 6 mechanisms to induce stress within stone (McGreevy 1981; Hall 2007). The freezing 7 temperature and rate of freezing (as well as stone moisture conditions) are thought to 8 be factors that determine the activity and efficacy of particular freeze-thaw 9 mechanisms. Aspect related differences in the establishment and persistence of sub$10 \quad 0^{\circ} \mathrm{C}$ temperatures is demonstrated by data whereby the higher stone temperatures 11 recorded in the SW facing block negate the potential for freeze-thaw weathering 12 effects while simultaneously, the NE facing block showed the potential for the 13 freezing of pore moisture with sub- $0^{\circ} \mathrm{C}$ temperatures recorded $5 \mathrm{~mm}$ below the block 14 surface. However, no breakdown of stone associated with freezing events occurred 15 during the recording period although that is not to say that freezing within the 16 substrate did not occur but was of insufficient duration, intensity and / or extent to 17 result in material breakdown and loss.

18 Finally, it is also important to acknowledge that temperature (along with moisture) exercises a critical control on stone-dwelling organisms. Stone temperature has recently been considered to comprise a significant and dynamic component of the

21 bio-receptivity of a stone surface in the context of lichen colonisation, to the extent 22 that an annual difference of just $3^{\circ} \mathrm{C}$ may be enough to determine whether a lichen 23 can or cannot survive on a particular surface (Mcllroy de la Rosa et al. 2013). 24 Equally, the persistence of moisture within stone can create conditions conducive to 25 the growth of algae on and within stone and this is an area of growing debate as to 
1 whether the observed increase in extensive algal growth on stone in temperate

2 environments and on different aspects is related to a shift to wetter winter conditions

3 related to climate change (Adamson et al, 2010, 2013).

\subsection{CONCLUSION}

6 Temperature is a key control on the operation and effectiveness of stone decay

7 processes, acting directly to influence change or indirectly to speed or slow change

8 through other mechanisms of decay. Under 'temperate' environmental conditions

9 data indicate that the thermal response of stone is not simple but is made up of

10 numerous short-term, small-scale fluctuations superimposed on the larger scale

11 diurnal cycles of heating and cooling. While the latter are quite predictable, the

12 former are less so and create conditions in the outer few millimetres of stone that

13 frequently fluctuate thereby providing repeated impulses for change in the presence

14 of moisture and contaminants such as salt.

15 The complexity of thermal response identified in the Peakmoor sandstone samples 16 investigated in this study means that unravelling the various feedback interactions

17 between components of the weathering system, so as to better understand the 18 dynamics of stone breakdown, is fraught with difficulties. Chief amongst these is the 19 interaction between physical heterogeneity (as expressed in porosity and 20 permeability differences between near surface and the deeper substrate - McCabe 21 et al, 2015), and thermal heterogeneity (with near surface conditions dominated by 22 rapid short-term fluctuations while more subdued conditions dominated by diurnal 23 heating and cooling cycles prevail in the deeper substrate). 
1 Moisture dynamics within sandstone are equally complex with data identifying a near-

2 surface region in which frequent moisture cycling takes place thereby creating the

3 potential for more weathering activity. Under certain conditions, where moisture

4 inputs exceed evaporative loss and where windspeeds are high, moisture can

5 penetrate beyond the dynamic near-surface zone $(5-10 \mathrm{~mm})$ to greater depth where

6 it may remain for lengthy periods of time particularly during winter months. Data also

7 indicated that the subsequent drying of stone takes much longer than initial wetting

8 because of the greater energy required to extract moisture from the stone.

9 Consequently once moisture starts to accumulate at depth it may become

10 increasingly difficult to remove especially when the hydraulic connection between

11 near-surface and deeper substrate regions of stone is disrupted resulting in the

12 subsequent loss of this deep moisture being reliant on the mechanism of vapour

13 diffusion alone.

14 Despite the complexity of the moisture characteristics and their spatial and temporal

15 variability, it is important to remember that the data reported here were gathered from

16 a type of sandstone that has relatively homogeneous structural and mineralogical

17 characteristics. Therefore, it seems reasonable to assume that the movement of

18 moisture in more heterogeneous and/or weathered sandstones maybe much more

19 complicated with structures such as clay laminations and variable pore sizes creating

20 complex hydraulic pathways that can draw moisture deeper into stone and restrict its

21 subsequent removal (McAllister et al, [In press]). Consequently, our understanding of

22 moisture dynamics in particular requires much more detailed investigation. 


\section{Acknowledgements}

2 The authors wish to acknowledge the contribution made to the inception of this 3 project by the late Professor Bernard Smith. During the period of this research, $\mathrm{Dr}$

4 Daniel McAlister was in receipt of post-graduate $\mathrm{PhD}$ funding from the Engineering 5 and Physical Sciences Research Council, UK (EPSRC Grant EP/G0151X/1). Finally, 6 the authors would like to acknowledge the reviewers insightful comments, which 7 have undoubtedly contributed to an improved final version of this paper.

8 


\section{References}

2 Adamson, C.S., McCabe, S., McAllister, D., Smith, B.J. \& Warke, P.A. 2010. Mapping the 3 spatial distribution of precipitation, biological soiling and decay on monuments in Northern 4 Ireland: towards understanding long-term stone response to moisture. XIX Congress of 5 the Carpathian Balkan Geological Association, Thessaloniki, Greece, Vol. 99, 183-190.

6 Adamson, C.S., McCabe, S., Warke, P.A., McAllister, D. \& Smith, B.J. 2013. The influence of 7 aspect on the biological colonization of stone in Northern Ireland. International Biodeterioration and Biodegradation, 84, 357-366.

Beall, C. 1998. Thermal and moisture protection manual: for architects, engineers and contractors. London, McGraw-Hill.

Betts, N.L. 1997. Climate. In: Cruickshank, J.G. (ed.) Soil and environment: Northern Ireland.

12 Belfast: Department of Agriculture for Northern Ireland and Queen's University Belfast, 6384.

14 Blocken, B. \& Carmeliet, J. 2004. A review of wind-driven rain research in building science. Journal of Wind Engineering and Industrial Areodynamics, 92, 1079-1130.

16 Briggen, P.M., Blocken, B.J.E. \& Schellen, H.L. 2009. Wind-driven rain on the façade of a monumental tower: numerical simulation, full-scale validation and sensitivity analysis. Building and Environment, 44, 1675-1690.

Building research establishment (BRE) 2000. Peakmoor Sandstone: Technical Data Sheet. http://projects.bre.co.uk/ConDiv/stonelist/peakmoor.html (Accessed 18.05.16).

21 Camuffo, D. 1995. Physical weathering of stone. Science of the Total Environment, 167, 114.

23 Camuffo, D. 1998. Microclimate for Cultural heritage. Elsevier, Amsterdam. 
1 Caputa, Z.A. 2016. The impact of solar radiation on the temperature of the exposed rocks of 2 the karst canyon (the Kraków-Częstochowa Upland, Poland). Bulletin of Geography. 3 Physical Geography Series, No.10: 19-30.

4 Collins, B.D \& Stock, G.M. 2016. Rockfall triggering by cyclic thermal stressing of exfoliation 5 fractures. Nature Geoscience, 9: 395-400.

6 Gómez-Heras, M., Smith, B.J. \& Fort, R. 2006. Surface temperature differences between 7

9 Gómez-Heras, M., Smith, B.J. \& Fort, R. 2008. Influence of surface heterogeneities of building granite on its thermal response and its potential for the generation of thermoclasty. Environmental Geology, 56, 547-560.

Goudie, A.S. \& Viles, H.A. 1997. Salt Weathering Hazards. Wiley, Chichester.

Gunzberger, Y. \& Merrien-Soukatchoff, V. 2011. Near-surface temperatures and heat balance of bare rock outcrops exposed to solar radiation. Earth Surface Processes and

Hall, K. 1997. Rock temperatures and implications for cold region weathering, 1: new data from Viking Valley, Alexander Island (Antarctica). Permafrost and Periglacial Processes,

Hall, K. 1999. The role of thermal stress fatigue in the breakdown of rock in cold regions. Geomorphology, 31, 47-63.

Hall, K. 2007. Monitoring of thermal conditions in building stone with particular reference to freeze-thaw events. In: Kourkoulis, S.K. (ed.) Fracture and Failure of Natural Building Stones. Springer, Dordrecht, 373-394.

Hall, K. \& André, M-F. 2001. New insights into rock weathering from high frequency rock temperature data: an Antarctic study of weathering by thermal stress. Geomorphology, 41, 23-35. 
1 Hall, K. \& André, M-F. 2003. Rock thermal data at the grain scale: applicability to granular disintegration in cold environments. Earth Surface Processes and Landforms, 28, 823836.

Hall, C. \& Hoff, W.D. 2002. Water Transport in Brick, Stone and Concrete. Taylor and Francis, New York.

Hall, K., Meiklejohn, I., Sumner, P. \& Arocena, J. 2010. Light penetration into Clarens 7 Sandstone and implications for deterioration of San Rock Art. Geoarchaeology, 25, 122136

Halsey, D.P., Mitchell, D.J. \& Dews, S.J. 1998. Influence of climatically induced cycles in physical weathering, Quarterly Journal of Engineering Geology, 31, 359-367.

Hillel, D. 1998. Environmental Soil Physics. Academic Press, London.

Iñigo, A.C. \& Vivente-Tavera, S. 2002. Surface-inside $(10 \mathrm{~cm})$ thermal gradients in granitic rocks: effect of environmental conditions. Building and Environment, 37, 101-108.

Jenkins, K.A. \& Smith, B.J. 1990. Daytime rock surface temperature variability and its implications for mechanical rock weathering in Tenerife, Canary Islands. Catena, 17, 449459.

McAllister, D., McCabe, S., Srinivasan, S., Smith, B.J. \& Warke, P.A. 2011. Moisture dynamics in building sandstone: implications for the transport and accumulation of salts. In: loannou, I \& Theodoridou, M. (eds) Salt Weathering on Buildings and Stone Sculptures, SWBSS 2011. Limassol, Cyprus, 39-46.

McAllister, D., McCabe, S., Smith, B.J., Srinivasan, S., \& Warke, P.A. 2013. Low temperature conditions in building sandstone: the role of extreme events in temperate environments.

McAllister, D., Warke, P.A., McCabe, S. \& Gomez-Heras, M. 2016. Evaporative moisture loss from heterogeneous stone: material-environment interactions during drying. Geomorphology 273, 308-322. 
1 McCabe, S., Smith, B.J. and Warke, P.A. 2007a. Preliminary observations on the impact of complex stress histories on sandstone response to salt weathering: laboratory simulations of process combinations. Environmental Geology, 52, 251-258.

McCabe, S., Smith, B.J. \& Warke, P.A. 2010. Exploitation of inherited weaknesses in firedamaged sandstone: the 'fatiguing' of 'shocked' stone. Engineering Geology, 115, 217225.

McCabe, S., Brimblecombe, P., Smith, B.J., McAllister, D., Srinivasan, S. \& Basheer, P.A.M. 2013. The use and meanings of 'time of wetness' in understanding building stone decay. Quarterly Journal of Engineering Geology and Hydrogeology, 46, 469-476.

McCabe, S., McAllister, D., Warke, P.A. \& Gomez-Heras, M. 2015. Building sandstone surface modification by biofilm and iron precipitation: emerging block-scale heterogeneity

McFadden, L.D., Eppes, M.C., Gillespie, A.R. \& Hallet, B. 2005. Physical weathering in arid landscapes due to diurnal variation in the direction of solar heating. Geological Society of America Bulletin, 117 (1/2), 161-173.

McGreevy, J.P. 1981. Some perspectives on frost shattering. Progress in Physical Geography, 5, 56-75.

McGreevy, J.P. \& Whalley, W.B. 1987. Progress report: weathering. Progress in Physical Geography, 11, 357-369.

Mcllroy de la Rosa, J.P., Casares Procel, M. \& Warke, P.A. 2013. Mapping stone surface temperature fluctuations: implications for lichen distribution and biomodification on historic stone surfaces. Journal of Cultural Heritage, 14, 346-353.

McKay, C.P., Molaro, J.P. \& Marinova, M.M. 2009. High frequency rock temperature data from hyper-arid desert environments in the Atacama and the Antarctic Dry Valleys and implications for rock weathering. Geomorphology, 110, 182-187. 
1 Molaro, J.P. \& McKay, C.P. 2010. Processes controlling rapid surface temperature variations on rock surfaces. Earth Surface Processes and Landforms, 35, 501-507.

Pel, L. \& Huinink, H. 2009. NMR imaging of moisture and ion transport in building materials. In: Codd, S.L. \& Seymour, J.D. (eds) Magnetic Resonance Microscopy, Wiley-VCH, Weinheim, 451-464.

Pérez-Bella, J.M., Dominguez-Hermándezz, J., Rodriquez-Soria, B., del Coz-Diaz, J.J. \& Cano-Sunen, E. 2013. Combined use of wind-driven rain and wind pressure to define water penetration risk into building facades: the Spanish case. Building and Environment, $64,46-56$.

Richter, D. \& Simmons, G. 1974. Thermal expansion behavior on igneous rocks. International Journal of Rock Mechanics and Mining Science and Geomechanics Abstracts, 11, 403-411.

Rodriguez-Navarro, C. \& Doehne, E. 1999. Salt weathering: influence of evaporation rate, supersaturation and crystallization pattern. Earth Surface Processes and Landforms, 24, 191-209.

Sass, O. 2003. Moisture distribution in rockwalls derived from 2D-resistivity measurements. Zeitschrift für Geomorphologie, Suppl. Bd., 132, 51-69.

Sass, O. 2005. Rock moisture measurements: techniques, results, and implications for weathering. Earth Surface Processes \& Landforms 30: 359-347.

Sass, O. \& Viles, H.A. 2010a. Wetting and drying of masonry walls: 2D-resistivity monitoring of driving rain experiments on historic stonework in Oxford, UK. Journal of Applied Geophysics, 70, 72-83.

Sass, O. \& Viles, H.A. 2010b. 2D resistivity surveys of the moisture content of historic limestone walls in Oxford, UK: implications for understanding catastrophic stone deterioration. In: Smith, B.J., Gómez-Heras, M., Viles, H.A. \& Cassar, J. (eds) Limestone in the Built Environment: Present Day Challenges for the Preservation of the Past. Geological 
Shokri, N. \& Or, D. 2011. What determines drying rates at the onset of diffusion controlled stage-2 evaporation from porous media? Water Resources Research, 47, W09513, doi:10.1029/2010WR010284.

Smith, B.J. 1977. Rock temperature measurements from the northwest Sahara and their implications for weathering. Catena, 41, 41-63.

Smith, B.J. 2009. Weathering processes and forms. In: Parsons, A.J. \& Abrahams, A.D. (eds) Geomorphology of Desert Environments (2 ${ }^{\text {nd }}$ edition), Springer, 69-100.

Smith, B.J. 2012. Weathering. In: Holden, J. (ed) An Introduction to Physical Geography and the Environment, Pearson, Essex, 185-214.

Smith, B.J., Srinivasan, S., Gómez-Heras, M., Basheer, P.A.M. \& Viles, H.A. 2008. Experimental studies of near-surface temperature and moisture cycling and surface wetting of stone and its implications for salt weathering. In: Ottosen, L.M., Rrig-Dalgaard, I., Larsen, P.K., Brajer, I., Bøllingstoft, P., Marciniak, M. and Svane, M. (eds) Proceedings from the International Conference of Salt Weathering on Buildings and Stone Sculptures, Copenhagen, October 2008, 65-77.

Smith, B.J., Srinivasan, S., Gómez-Heras, M., Basheer, P.A.M. \& Viles, H.A. 2011. Nearsurface temperature cycling of stone and its implications for the scales of surface deterioration. Geomorphology, 130, 76-82.

Srinivasan, S., Basheer, P.A.M., Smith, B.J., Gómez-Heras, M., Grattan, K.T.V. \& Sun, T. 2010. Use of fiber-optic and electrical resistance sensors for monitoring moisture movement in building stone subjected to simulated climatic conditions. Journal of ASTM International, 7, January 2010. content in building materials using a wireless passive sensor. Sensors, 10, 4270-4280. 
1 Turkington, A.V., Smith, B.J. \& Basheer, P.A.M. 2002. The effect of block retreat on 2 subsurface temperature and moisture conditions in sandstone. In: Prikryl, R. \& Viles, H.A. 3 (eds) Understanding and Managing Stone Decay. Karolinum Press, Prague, 116-126.

4 Viles, H.A. 2005. Microclimate and weathering in the central Namib Desert, Namibia. 5 Geomorphology, 67, 189-209

6 Warke, P.A. 2000. Micro-environmental conditions and rock weathering in hot, arid regions.

7 Zeitschrift für Geomorphologie Supplement, 120, 83-95.

8 Warke, P.A. and Smith, B.J. 1994. Short-term rock temperature fluctuations under simulated 9 hot desert conditions: some preliminary data. In: Robinson, D.A. \& Williams, R.B.G. (eds) 10 Rock Weathering and Landform Evolution. Wiley, Chichester, 57-70.

11 Yatsu, E. 1088. The Nature of Weathering: An Introduction. Sozosha, Tokyo. 


\section{$1 \quad$ LIST OF TABLE CAPTIONS}

2 Table 1: Examples of investigations of stone temperatures in the natural

3 environment.

4 Table 2: Summary of structural and mineralogical properties of Peakmoor 5 Sandstone.

6 Table 3: Average winter and summer values based on Met Office data collected over 730 years from 1981-2010.

8 Table 4a: Summary of air temperature and subsurface stone temperature conditions 9 at 5, 10, 20, 50 and $100 \mathrm{~mm}$ depths during the June-July recording period.

10 Table 4b: Summary of air temperature and subsurface stone temperature conditions 11 at 5, 10, 20, 50 and $100 \mathrm{~mm}$ depths during the October-December recording period.

12 Table 5: Data showing rate of movement of wetting front in relation to rainfall events. 13 These data should be read in conjunction with the graphs in Figure 9 where the 14 numbered rainfall events are identified as 1, 2, 3, and 4.

Table 1

\begin{tabular}{|c|c|c|c|c|}
\hline Author(s) & Location & Material & $\begin{array}{l}\text { Recording } \\
\text { Frequency }\end{array}$ & $\begin{array}{l}\text { Depth of Measure- } \\
\text { ment from Surface } \\
(\mathrm{mm})\end{array}$ \\
\hline Smith (1977) & Morocco; Tunisia & Limestone & $20 \min$ & 50,100 \\
\hline Hall (1997) & Antarctica & Sandstone & 1, 2 min & $0,5,10,15,30,50$ \\
\hline $\begin{array}{l}\text { Halsey et al, } \\
\text { (1998) }\end{array}$ & United Kingdom & Quartz Arenite & $15 \mathrm{~min}$ & 25 \\
\hline $\begin{array}{l}\text { Warke \& Smith } \\
\text { (1998) }\end{array}$ & USA & $\begin{array}{l}\text { Sandstone, } \\
\text { Granite, Marble, } \\
\text { Limestone }\end{array}$ & $1 \mathrm{~min}$ & 0,25 \\
\hline $\begin{array}{l}\text { Hall \& André } \\
\text { (2001) }\end{array}$ & Antarctica & Granodiorite & $1 \mathrm{~min}$ & 0 \\
\hline $\begin{array}{l}\text { Inigo \& Vicente- } \\
\text { Tavera (2002) }\end{array}$ & Spain & Granite & $4 \mathrm{hr}$ & 10 \\
\hline Viles (2005) & Namibia & Marble, Granite & $3 \mathrm{hr}, 1 \mathrm{~min}$ & 0 \\
\hline $\begin{array}{l}\text { McKay et al, } \\
\text { (2009) }\end{array}$ & Chile, Antarctica & Dolerite & $1 \mathrm{~s}$ & 0 \\
\hline Hall et al (2010) & South Africa & Sandstone & $2 \min$ & $0,0.5,1$ \\
\hline $\begin{array}{l}\text { Molaro \& McKay } \\
(2010)\end{array}$ & USA & $\begin{array}{l}\text { Dolerite, } \\
\text { Sandstone }\end{array}$ & $0.375 \mathrm{~s}$ & 0 \\
\hline $\begin{array}{l}\text { Gunzburger \& } \\
\text { Merrien- } \\
\text { Soukatchoff } \\
(2011)\end{array}$ & France & Gneiss & $1 \mathrm{hr}$ & $\begin{array}{l}<10, \quad 100,200,300 \\
400,500\end{array}$ \\
\hline Caputa (2016) & Poland & Limestone & $1 \mathrm{hr} ?$ & 0,50 \\
\hline
\end{tabular}


Table 2:

\begin{tabular}{|c|c|c|}
\hline Property & Value & Comment / Data Source \\
\hline Age & Carboniferous (360-300 Ma) & Part of the Millstone Grit Group \\
\hline Primary Mineralogy & Quartz & $\begin{array}{l}\text { Illite and kaolinite are present as } \\
\text { diagenetic clay phases }\end{array}$ \\
\hline Apparent Density & $2264.50 \mathrm{~kg} / \mathrm{m}^{3}$ & Original measurement \\
\hline Porosity accessible to $\mathrm{H}_{2} \mathrm{O}$ & $16.46 \%$ & BRE 2000 \\
\hline Porosity accessible to $\mathrm{Hg}$ & $16.37 \%$ & Original measurement \\
\hline Mean Pore Diameter & $0.31 \mu \mathrm{m}$ & Original measurement \\
\hline Average Air Permeability & $31.67 \mathrm{mD}$ & McCabe et al, 2007 \\
\hline Saturation Coefficient & 0.68 & BRE 2000 \\
\hline Water Absorption Capacity & $5.07 \%$ & BRE 2000 \\
\hline
\end{tabular}

2

Table 3:

\begin{tabular}{llccccc}
\hline Location & Month & $\begin{array}{c}\text { Max. Temp } \\
\left({ }^{\circ} \mathbf{C}\right)\end{array}$ & $\begin{array}{c}\text { Min. Temp } \\
\left({ }^{\circ} \mathbf{C}\right)\end{array}$ & $\begin{array}{c}\text { Frost } \\
\text { Days }\end{array}$ & $\begin{array}{c}\text { Rainfall } \\
(\mathbf{m m})\end{array}$ & $\begin{array}{c}\text { Rain Days } \\
>\mathbf{m m}\end{array}$ \\
\hline Belfast & January & 7.9 & 2.2 & 7.5 & 90.4 & 14.7 \\
& July & 19.7 & 11.7 & 0.0 & 66.0 & 12.1 \\
\hline
\end{tabular}

6

7

8

Table 4a

\begin{tabular}{|c|c|c|c|c|c|}
\hline \multirow[b]{2}{*}{$\begin{array}{l}\text { Sensor Depth } \\
\text { From Surface }\end{array}$} & \multicolumn{4}{|c|}{ Block Temperatures $\left({ }^{\circ} \mathrm{C}\right)$ - June-July } & \multirow[b]{2}{*}{$\begin{array}{c}\text { Air } \\
\text { Temperature }\end{array}$} \\
\hline & $\begin{array}{c}\text { Northeast } \\
\text { Facing }\end{array}$ & $\begin{array}{l}\text { Southeast } \\
\text { Facing }\end{array}$ & $\begin{array}{c}\text { Southwest } \\
\text { Facing }\end{array}$ & $\begin{array}{c}\text { Northwest } \\
\text { Facing } \\
\end{array}$ & \\
\hline \multicolumn{6}{|l|}{$5 \mathrm{~mm}$} \\
\hline Mean & 16.3 & 16.3 & 16.4 & 16.0 & 11.4 \\
\hline Maximum & 26.7 & 31.2 & 34.6 & 29.5 & 23.5 \\
\hline Minimum & 6.0 & 5.8 & 6.1 & 5.9 & 5.9 \\
\hline Range & 20.7 & 25.5 & 28.5 & 23.5 & 17.6 \\
\hline \multicolumn{6}{|l|}{$10 \mathrm{~mm}$} \\
\hline Mean & 16.2 & 16.3 & 16.4 & 16.0 & 11.4 \\
\hline Maximum & 26.6 & 31.2 & 34.3 & 29.2 & 23.5 \\
\hline Minimum & 5.9 & 5.7 & 6.1 & 6.0 & 5.9 \\
\hline Range & 20.7 & 25.8 & 28.2 & 23.2 & 17.6 \\
\hline \multicolumn{6}{|l|}{$20 \mathrm{~mm}$} \\
\hline Mean & 16.3 & 16.3 & 16.3 & 15.9 & 11.4 \\
\hline Maximum & 26.6 & 31.2 & 33.9 & 29.1 & 23.5 \\
\hline Minimum & 6.0 & 5.7 & 6.0 & 5.9 & 5.9 \\
\hline Range & 20.6 & 25.4 & 27.9 & 23.2 & 17.6 \\
\hline \multicolumn{6}{|l|}{$50 \mathrm{~mm}$} \\
\hline Mean & 16.2 & 16.3 & 16.3 & 15.9 & 11.4 \\
\hline Maximum & 26.5 & 30.4 & 33.1 & 28.4 & 23.5 \\
\hline Minimum & 6.1 & 5.9 & 6.1 & 6.1 & 5.9 \\
\hline Range & 20.3 & 24.4 & 26.9 & 22.4 & 17.6 \\
\hline \multicolumn{6}{|l|}{$100 \mathrm{~mm}$} \\
\hline Mean & 16.1 & 16.1 & 16.2 & 15.8 & 11.4 \\
\hline Maximum & 26.3 & 29.1 & 31.9 & 27.5 & 23.5 \\
\hline Minimum & 6.4 & 5.9 & 6.1 & 6.0 & 5.9 \\
\hline Range & 20.0 & 23.2 & 25.8 & 21.4 & 17.6 \\
\hline
\end{tabular}


2 Table 4b

\begin{tabular}{|c|c|c|c|c|c|}
\hline \multirow[b]{2}{*}{$\begin{array}{l}\text { Sensor Depth } \\
\text { From Surface }\end{array}$} & \multicolumn{4}{|c|}{ Block Temperatures $\left({ }^{\circ} \mathrm{C}\right)$ - October-December } & \multirow[b]{2}{*}{$\begin{array}{c}\text { Air } \\
\text { Temperature }\end{array}$} \\
\hline & $\begin{array}{l}\text { Northeast } \\
\text { Facing }\end{array}$ & $\begin{array}{c}\text { Southeast } \\
\text { Facing }\end{array}$ & $\begin{array}{c}\text { Southwest } \\
\text { Facing }\end{array}$ & $\begin{array}{l}\text { Northwest } \\
\text { Facing }\end{array}$ & \\
\hline \multicolumn{6}{|l|}{$5 \mathrm{~mm}$} \\
\hline Mean & 7.4 & 7.9 & 7.7 & 7.1 & 8.0 \\
\hline Maximum & 17.0 & 21.9 & 23.0 & 17.9 & 17.0 \\
\hline Minimum & -2.5 & -2.4 & -2.4 & -2.5 & -0.3 \\
\hline Range & 19.5 & 24.4 & 25.5 & 20.3 & 17.3 \\
\hline \multicolumn{6}{|l|}{$10 \mathrm{~mm}$} \\
\hline Mean & 7.4 & 7.9 & 7.6 & 7.2 & 8.0 \\
\hline Maximum & 17.0 & 21.9 & 22.9 & 17.9 & 17.0 \\
\hline Minimum & -2.5 & -2.5 & -2.5 & -2.4 & -0.3 \\
\hline Range & 19.5 & 25.0 & 25.4 & 20.2 & 17.3 \\
\hline \multicolumn{6}{|l|}{$20 \mathrm{~mm}$} \\
\hline Mean & 7.4 & 7.8 & 17.6 & 7.1 & 8.0 \\
\hline Maximum & 17.0 & 21.9 & 22.5 & 17.7 & 17.0 \\
\hline Minimum & -2.5 & -2.5 & -2.4 & -2.5 & -0.3 \\
\hline Range & 19.5 & 24.4 & 24.9 & 20.2 & 17.3 \\
\hline \multicolumn{6}{|l|}{$50 \mathrm{~mm}$} \\
\hline Mean & 7.3 & 7.9 & 7.6 & 7.2 & 8.0 \\
\hline Maximum & 16.7 & 20.7 & 21.9 & 17.5 & 17.0 \\
\hline Minimum & -2.6 & -2.3 & -2.5 & -2.5 & -0.3 \\
\hline Range & 19.3 & 23.0 & 24.3 & 20.0 & 17.3 \\
\hline \multicolumn{6}{|l|}{$100 \mathrm{~mm}$} \\
\hline Mean & 7.5 & 7.7 & 7.6 & 7.1 & 8.0 \\
\hline Maximum & 16.8 & 19.6 & 20.9 & 17.0 & 17.0 \\
\hline Minimum & -2.4 & -2.5 & -2.4 & -2.5 & -0.3 \\
\hline Range & 19.3 & 22.0 & 23.3 & 19.5 & 17.3 \\
\hline
\end{tabular}

4

5

$6 \quad$ Table 5

\begin{tabular}{|c|c|c|c|c|c|c|c|}
\hline \multirow[t]{2}{*}{$\begin{array}{l}\text { Block } \\
\text { Aspect }\end{array}$} & \multirow{2}{*}{$\begin{array}{l}\text { Date of } \\
\text { Detection } \\
\text { at } 5 \mathrm{~mm}\end{array}$} & \multirow{2}{*}{$\begin{array}{l}\text { Rainfall } \\
\text { Total \& } \\
\text { Duration }\end{array}$} & \multicolumn{5}{|c|}{$\begin{array}{c}\text { Time of arrival of wetting front in minutes following } \\
\text { detection at } 5 \mathrm{~mm}\end{array}$} \\
\hline & & & $5 \mathrm{~mm}$ & $10 \mathrm{~mm}$ & $20 \mathrm{~mm}$ & $50 \mathrm{~mm}$ & $100 \mathrm{~mm}$ \\
\hline $\begin{array}{l}\text { (1) North- } \\
\text { west }\end{array}$ & 17.07 .2011 & $\begin{array}{l}4.2 \mathrm{~mm} \text { over } \\
\text { previous } 2 \\
\text { days }\end{array}$ & $\begin{array}{l}\text { Datum } \\
\text { point }\end{array}$ & 5 & 135 & 755 & - \\
\hline $\begin{array}{l}\text { (2) North- } \\
\text { east }\end{array}$ & 12.06 .2011 & $\begin{array}{l}7.6 \mathrm{~mm} \text { over } \\
\text { previous } 2 \\
\text { days }\end{array}$ & $\begin{array}{l}\text { Datum } \\
\text { point }\end{array}$ & 70 & 125 & 515 & - \\
\hline $\begin{array}{l}\text { (3) North- } \\
\text { east }\end{array}$ & 07.07 .2011 & $\begin{array}{l}1.4 \mathrm{~mm} \text { in } \\
\text { preceding } 15 \\
\text { hours }\end{array}$ & $\begin{array}{l}\text { Datum } \\
\text { point }\end{array}$ & 75 & 125 & - & - \\
\hline $\begin{array}{l}\text { (4) South- } \\
\text { east }\end{array}$ & 17.06 .2011 & $\begin{array}{l}2.8 \mathrm{~mm} \text { in } \\
\text { preceding } 10 \\
\text { hours }\end{array}$ & $\begin{array}{l}\text { Datum } \\
\text { point }\end{array}$ & 60 & 85 & 520 & - \\
\hline
\end{tabular}

7

8 


\section{FIGURES}

2

3 Figure 1: Porosity characteristics of Peakmoor Sandstone derived from Mercury 4 Intrusion Porosimetry (MIP) analysis.

5

6

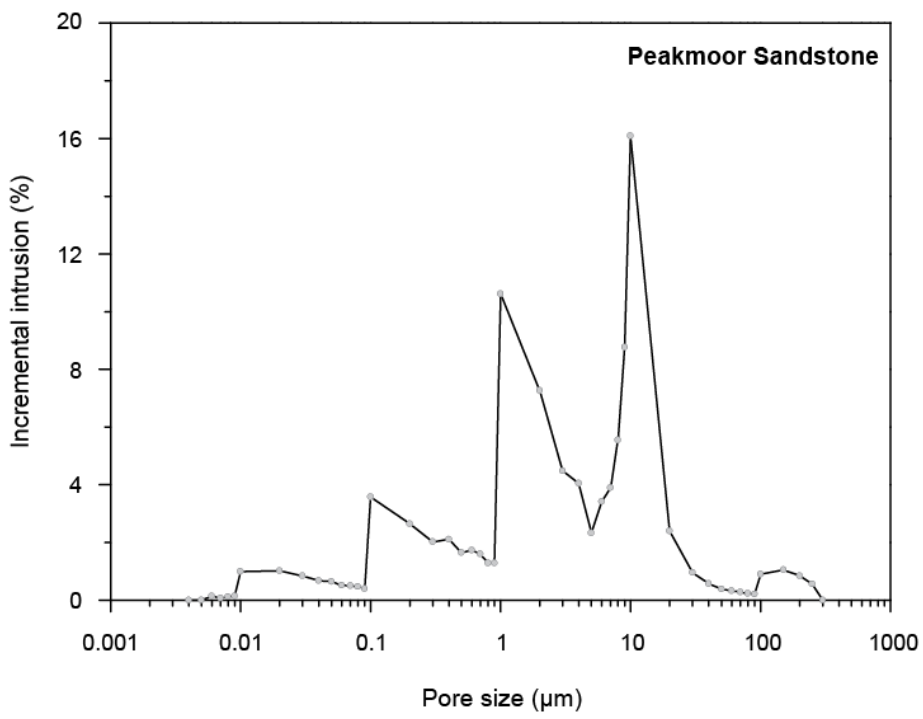

Porous media characterisation

Connected porosity (\%)

Micro $<5 \mu \mathrm{m}$ (\% total porosity) $\quad 50.9$

Macro $>5 \mu m(\%$ total porosity) $\quad 49.1$

$<0.01 \mu m=0.47$ 0.01 to $0.1 \mu \mathrm{m}=\quad 6.06$ 0.1 to $1 \mu \mathrm{m}=17.91$

1 to $10 \mu \mathrm{m}=50.37$ 10 to $100 \mu m=21.45$ $>100 \mu m=3.74$

Specific surface area $\left(\mathrm{m}^{2} / \mathrm{g}\right) \quad 0.93$ Tortuosity $(\mu \mathrm{m}) \quad 5.24$ Average pore diameter 4V/A ( $\mu \mathrm{m}) \quad 0.31$

Apparent density at $1.4 \mathrm{psi}(\mathrm{g} / \mathrm{ml}) \quad 2.24$ Real density $(\mathrm{g} / \mathrm{ml}) \quad 2.68$

Figure 2: Location of field exposure site.

10

11
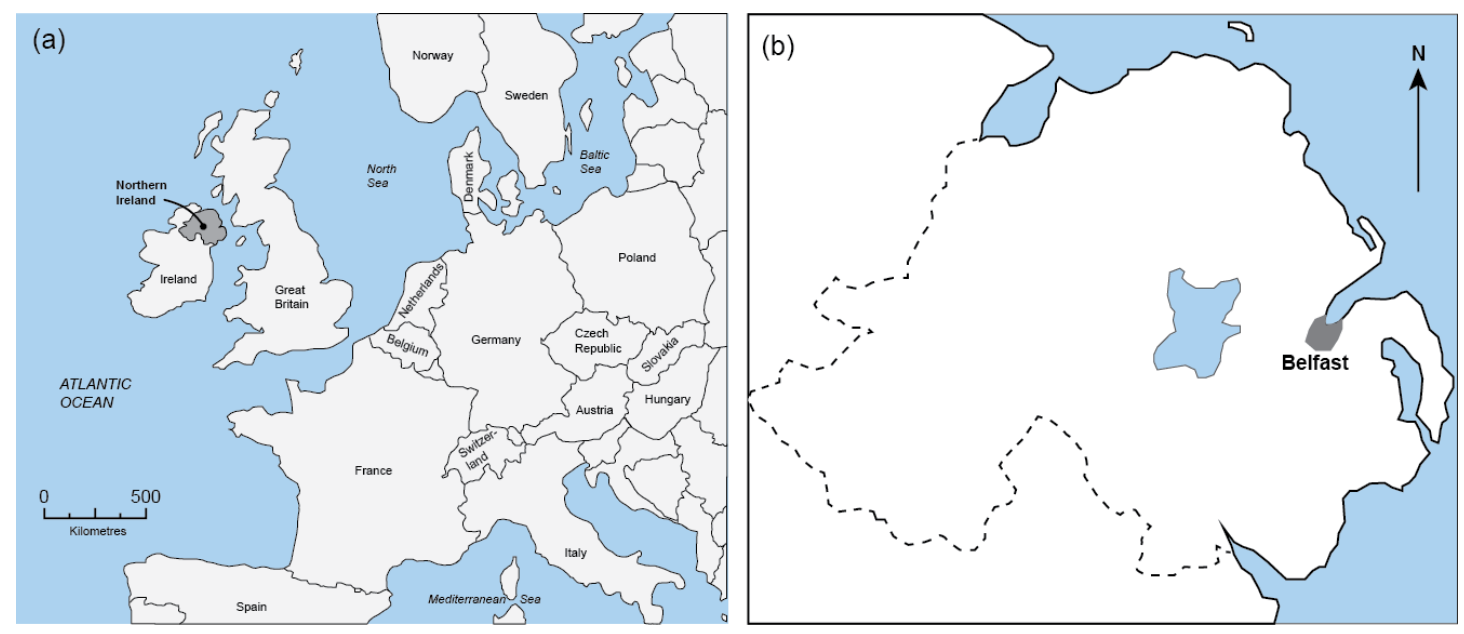
Figure 3: Experimental test unit with Peakmoor Sandstone samples in situ.

2

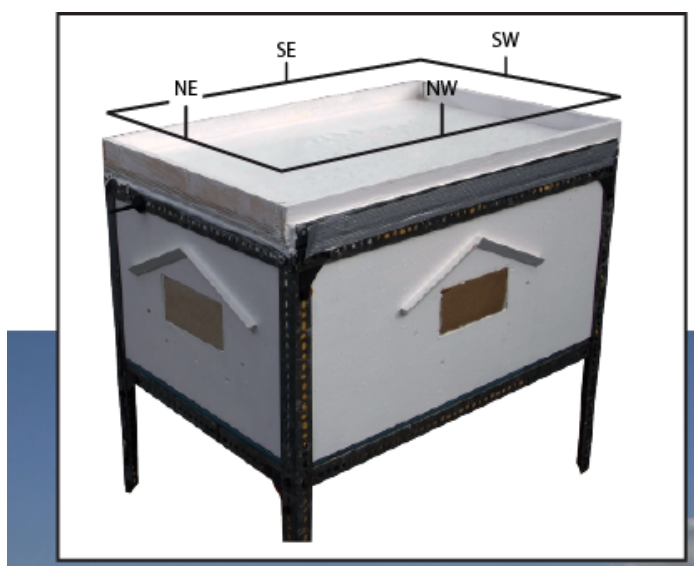

3

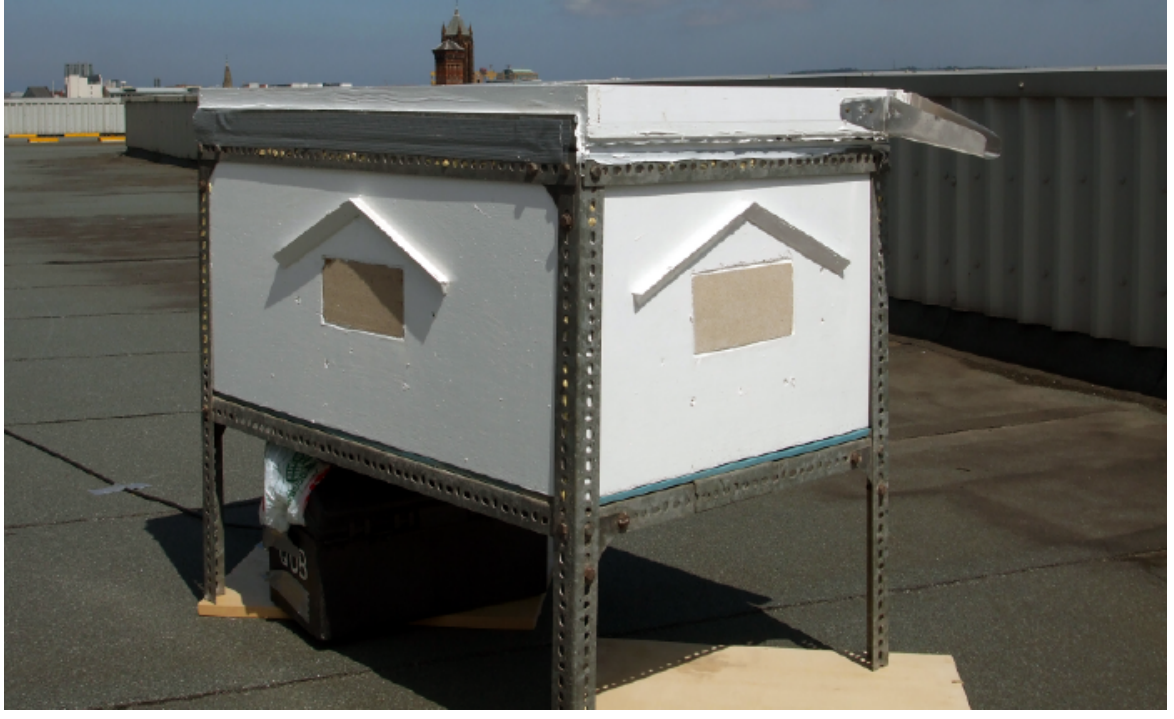

5 
Figure 4: Diagram of test blocks showing: a) positioning and depth of the embedded temperature and moisture sensors (rear view); b) how each drilled sensor cavity was sealed (side view); c) position of sensors in cross-section.

4

(a) Rear face of block showing the position of sensors and depth from the surface

(b) General overview of method of sensor insertion

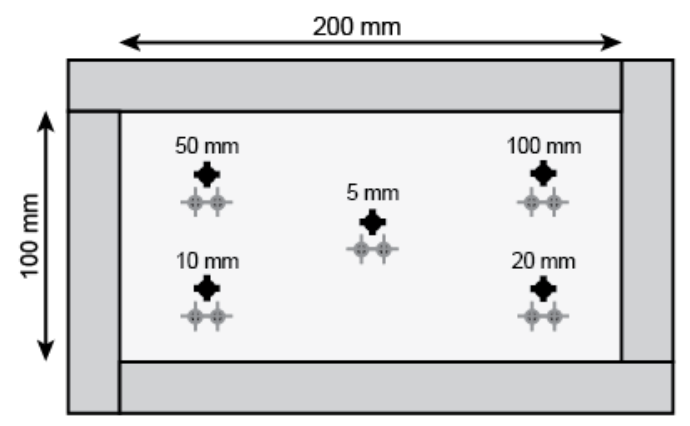

$50 \mathrm{~mm}$ Depth of sensor(s) from stone surface

$\downarrow$ Thermistor (Temperature)

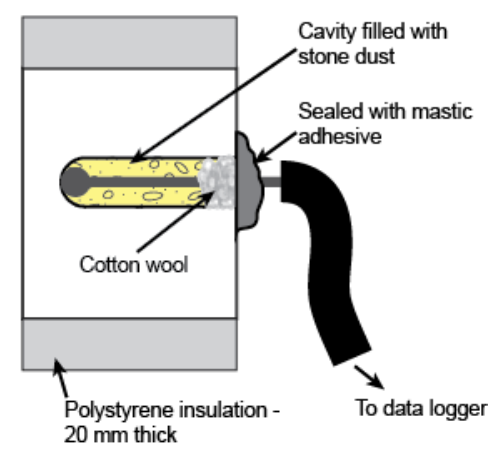

$-\phi \quad$ Two-pin resistivity electrodes (Moisture)

(c) Position of sensors in cross-section

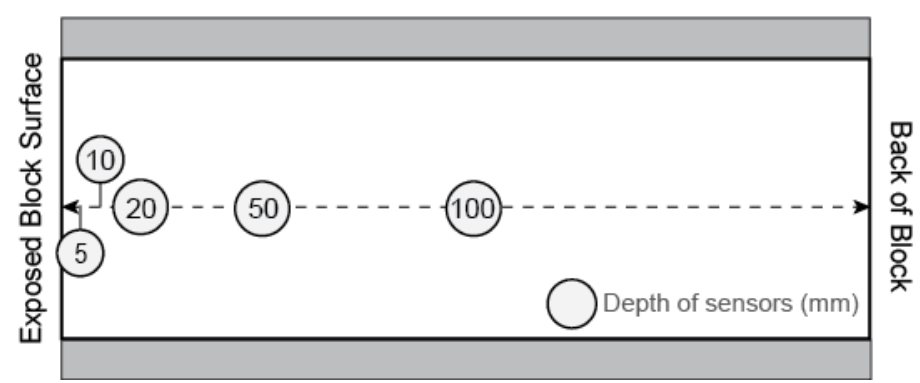


Figure 5a: Temperature data from 5, 10, 20, 50 and $100 \mathrm{~mm}$ below the surface of the northeast (NE) and southwest (SW) facing blocks collected during the June-July recording period.
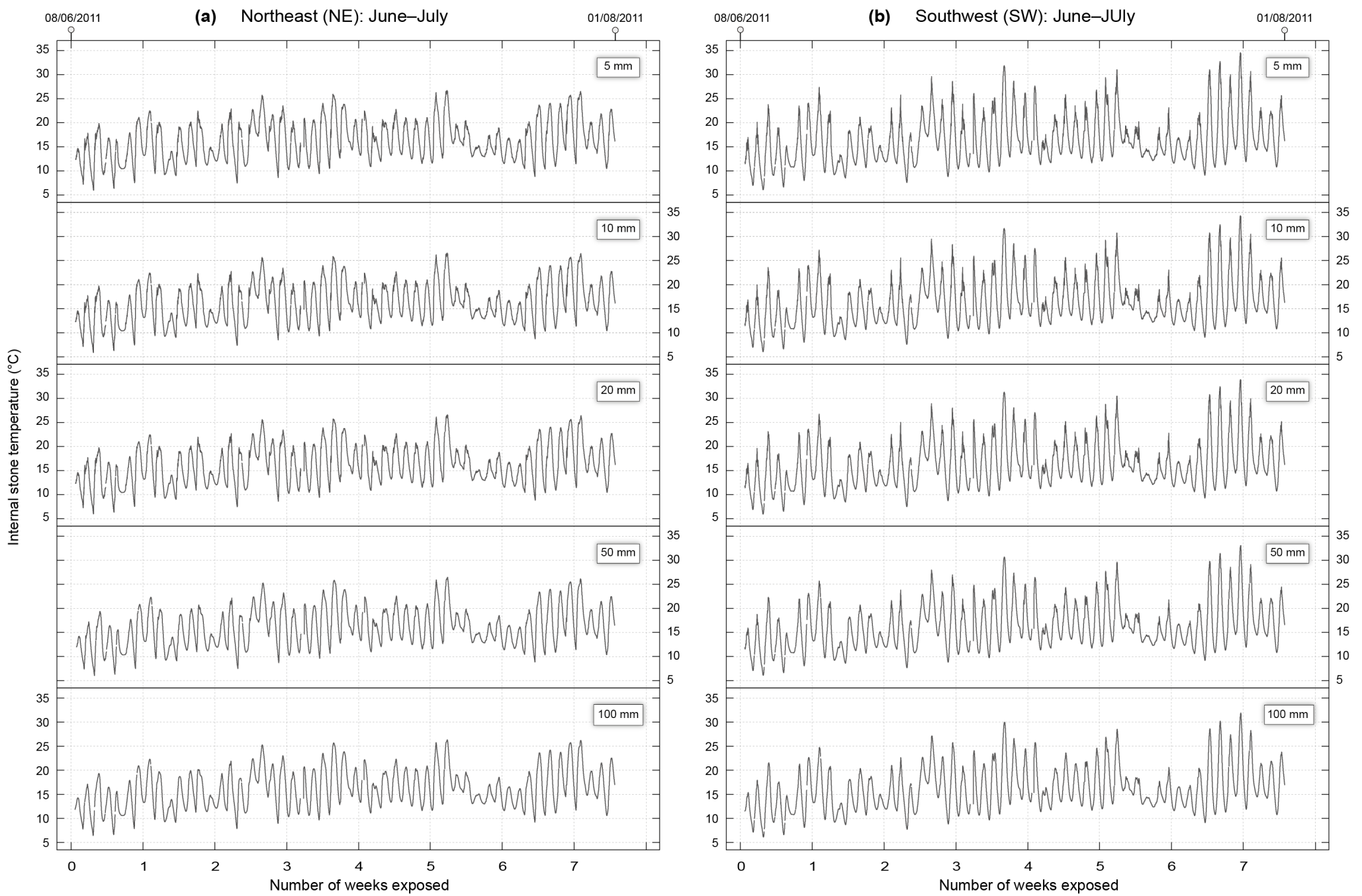
Figure 5b: Temperature data from 5, 10, 20, 50 and $100 \mathrm{~mm}$ below the surface of the northeast (NE) and southwest (SW) facing blocks collected during the October-December recording period
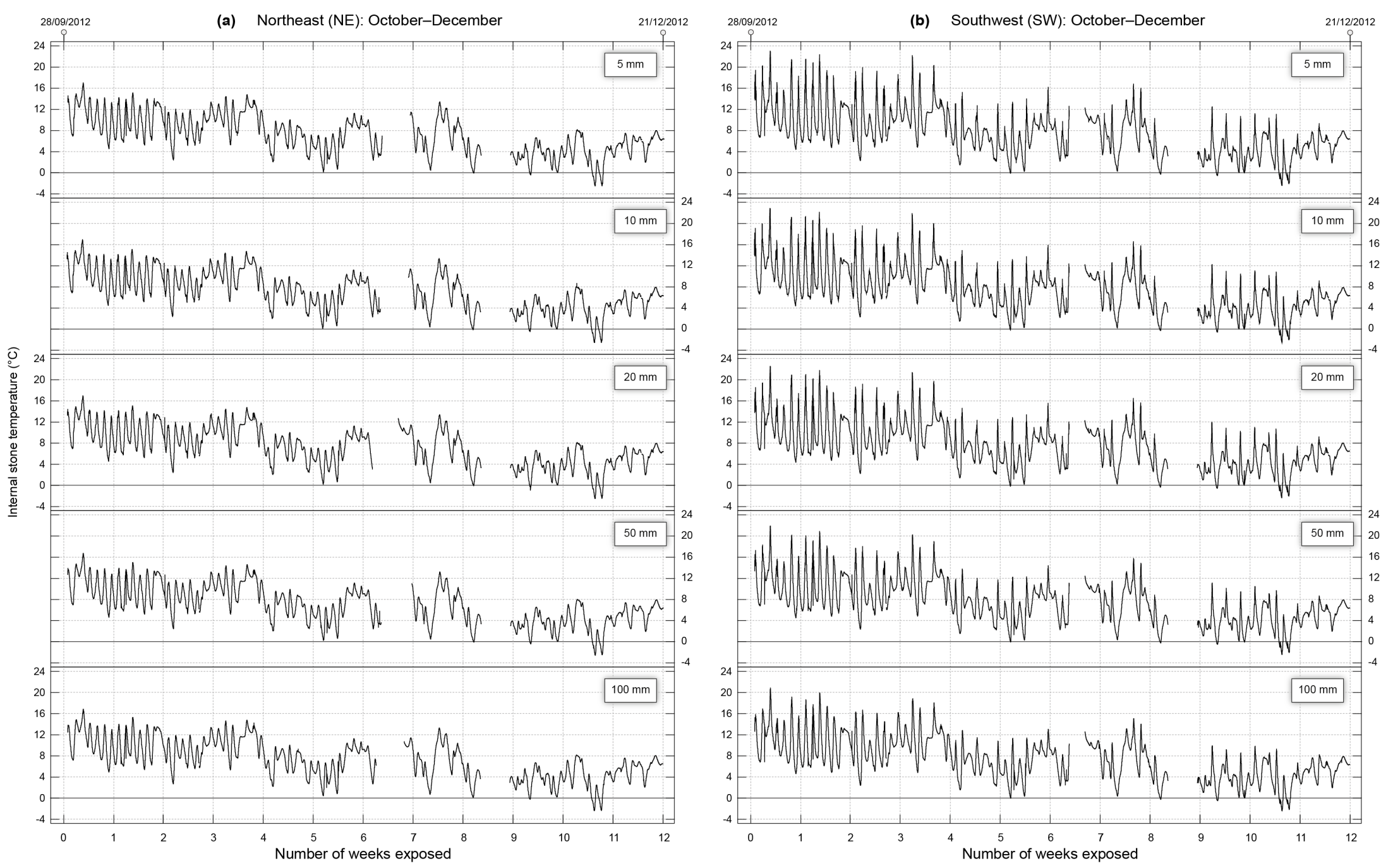
Figure 6: Air temperature conditions and internal stone temperatures (5 mm depth) according to aspect during: a) overcast conditions; and, b) clear sky conditions - data were collected in the near-surface structure during the June-July monitoring at 5minute intervals; it is important to note the different temperature scale in the temperature data presented in the insets.

(a) Cloudy overcast conditions
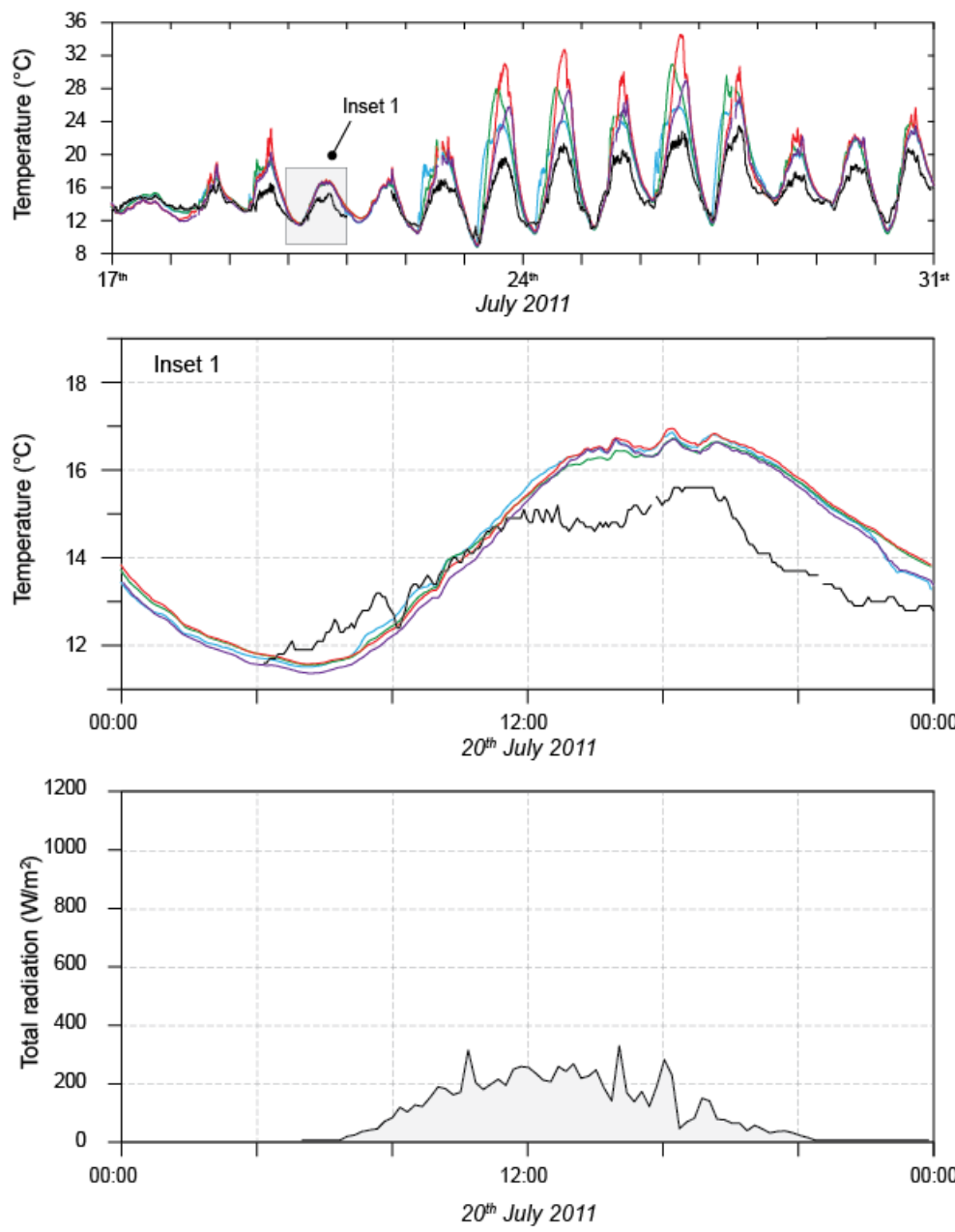

(b) Clear sky conditions
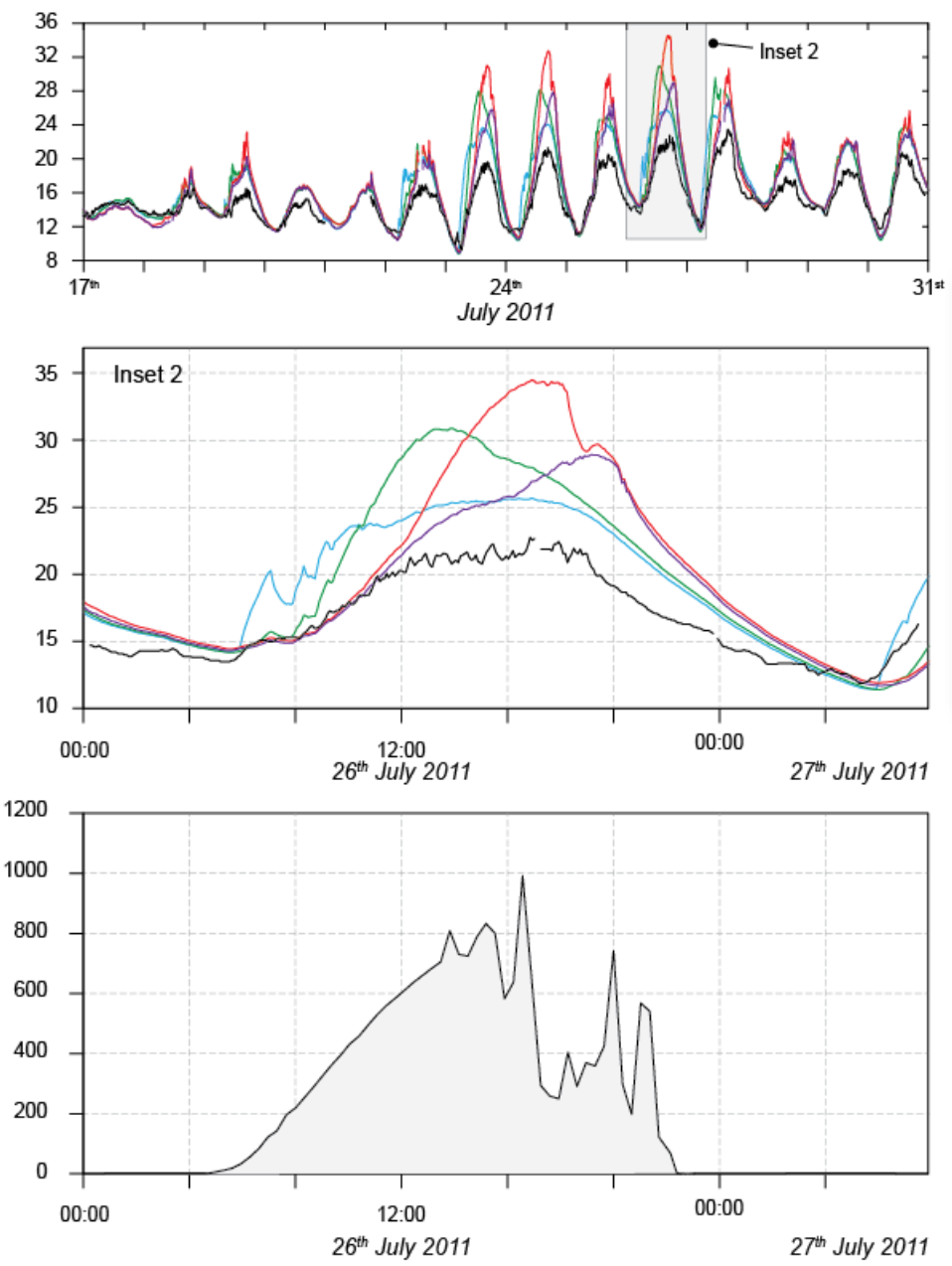

$$
26^{\text {th }} \text { July } 2011
$$

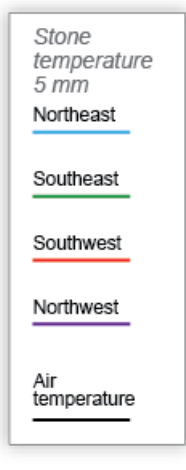

4$$
\begin{array}{|l|}
\hline \begin{array}{l}
\text { Stone } \\
\text { temperature } \\
5 \mathrm{~mm} \\
\text { Northeast } \\
\hline \text { Southeast } \\
\hline \text { Southwest } \\
\hline \text { Northwest } \\
\hline \text { Air } \\
\text { temperature } \\
\hline
\end{array} \\
\hline
\end{array}
$$ 
Figure 7: (a) Three day series of temperature data recorded $5 \mathrm{~mm}$ below the block surfaces from all exposure aspects; (b) total solar radiation recorded over the same period.

4

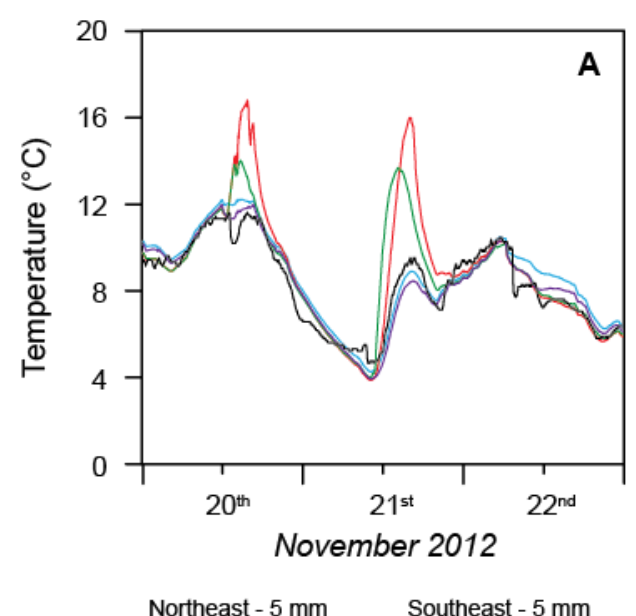

Northeast - $5 \mathrm{~mm}$

Southeast - $5 \mathrm{~mm}$

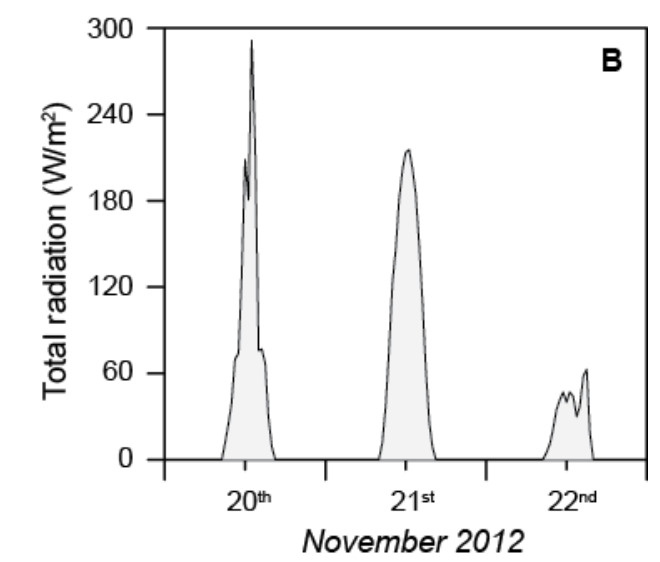

Southwest - $5 \mathrm{~mm}$

Northwest - $5 \mathrm{~mm}$

Air temperature

5
6

7 
Figure 8: Depth-related temperature differences recorded in (a) the northeast facing block and, (b) the southwest-facing block with selected detail from both datasets shown in the relevant insets.

(a) Northeast (NE) Block

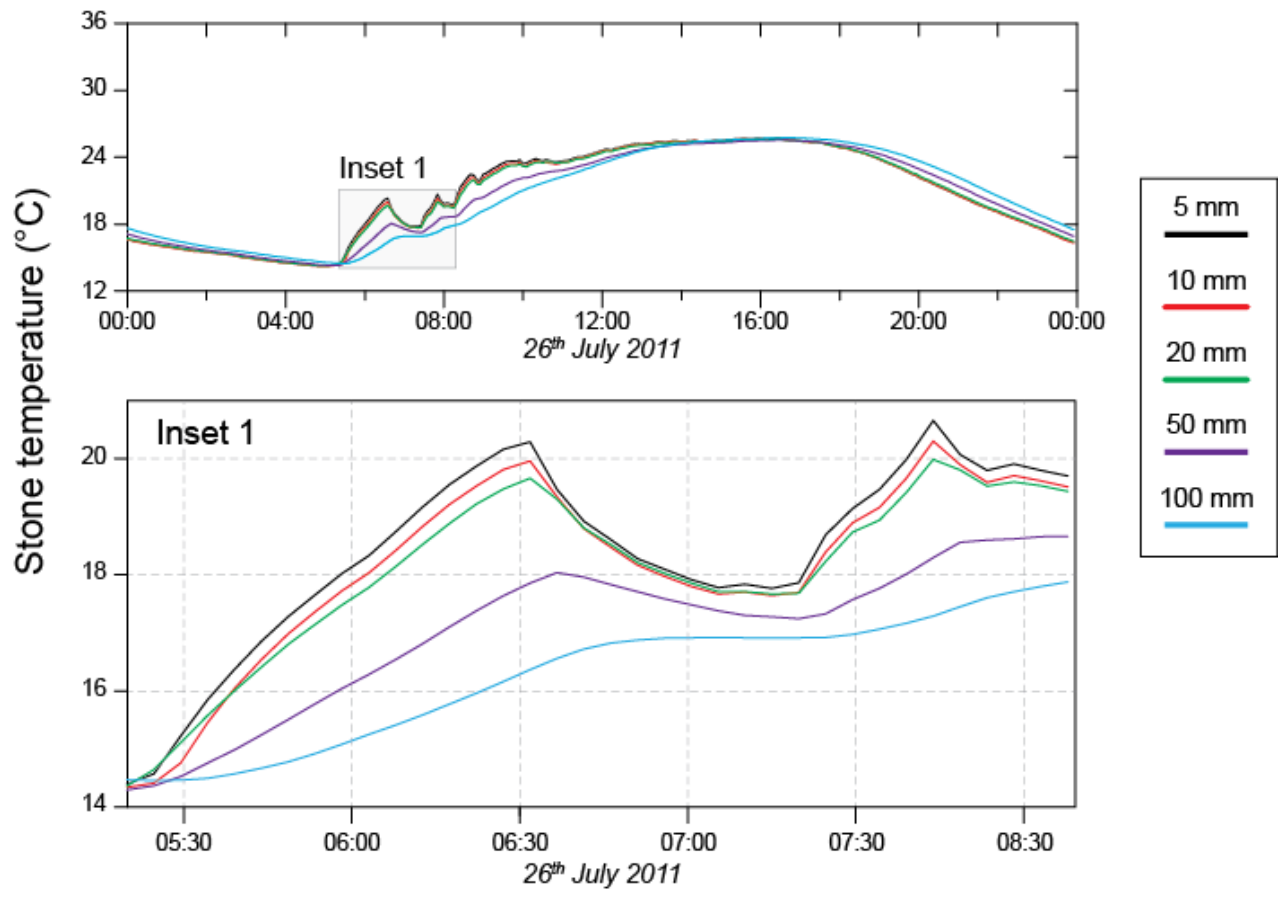

(b) Southwest (SW) Block
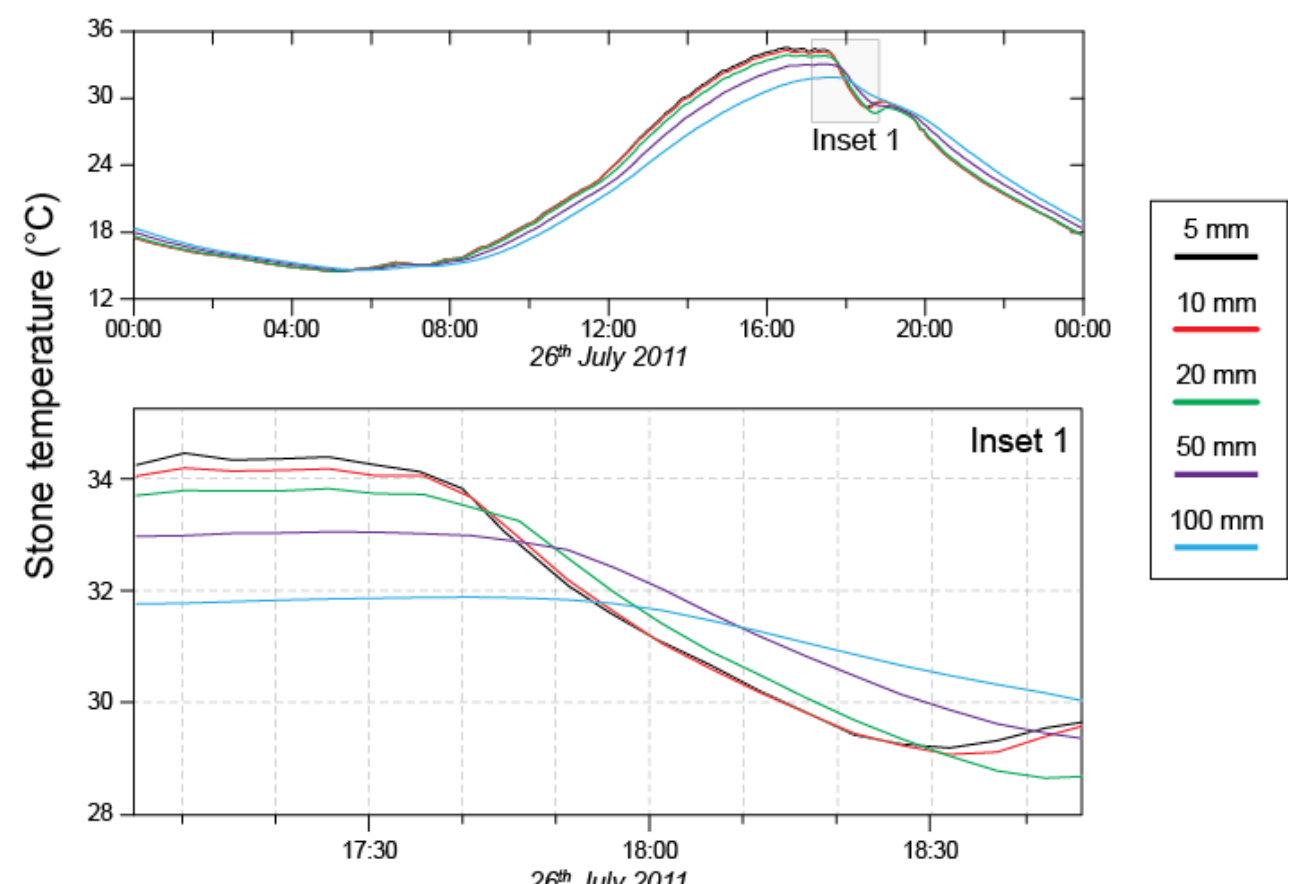
Figure 9: Development of wetting fronts in all Peakmoor Sandstone samples identified during the June-July recording period. Unfortunately data from the sensor located at $5 \mathrm{~mm}$ below the surface of the southwest facing block is missing because of technical problems with the sensor.
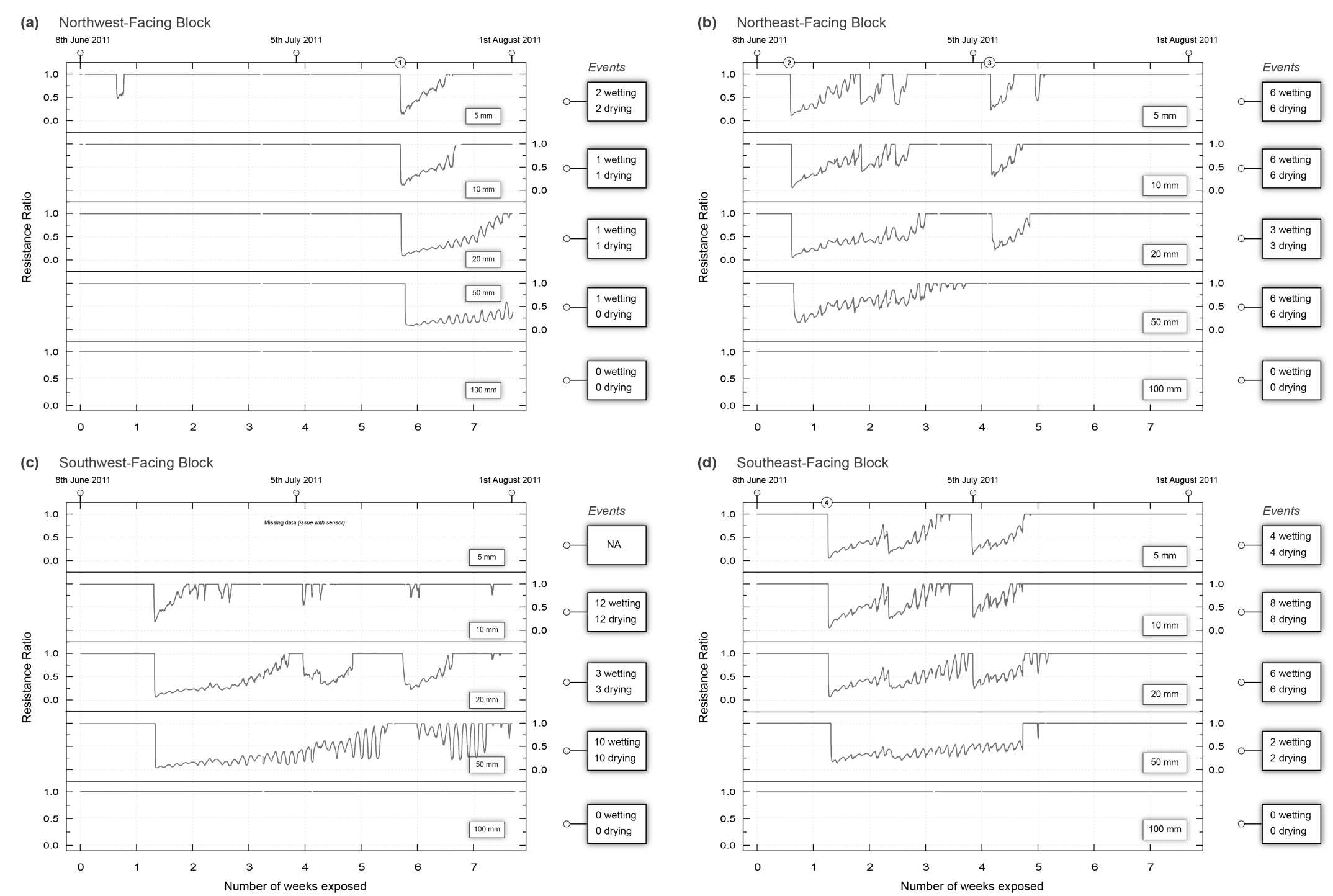
Figure 10: Arrival of wetting front (light grey shaded vertical line) at $5 \mathrm{~mm}$ depth in northeast-facing sample and links with the prevailing meteorological conditions. (a \& b) resistivity data and rainfall totals on 10-12 June and 7 July; (c \& d) windspeed, air temperature and relative humidity on 10-12 June; (e \& f) windspeed, air temperature and relative humidity on 7 July.

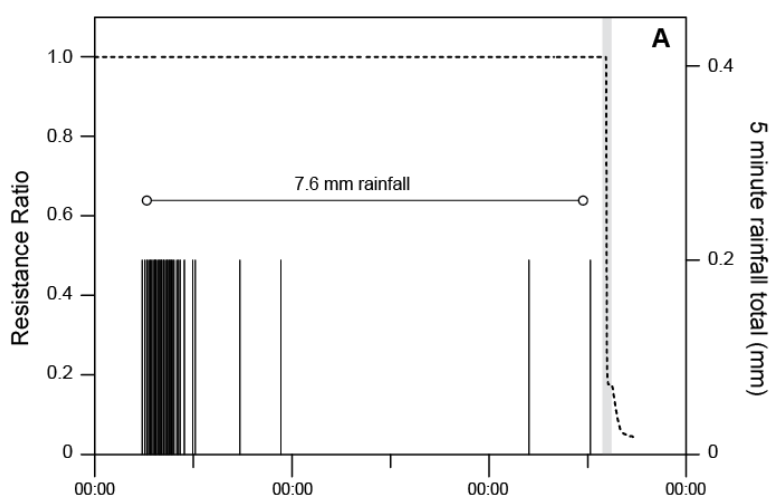

$10^{\text {th }}$ June $11^{\text {th }}$ June $12^{\text {th }}$ June

.... Resistance Ratio at $5 \mathrm{~mm}$

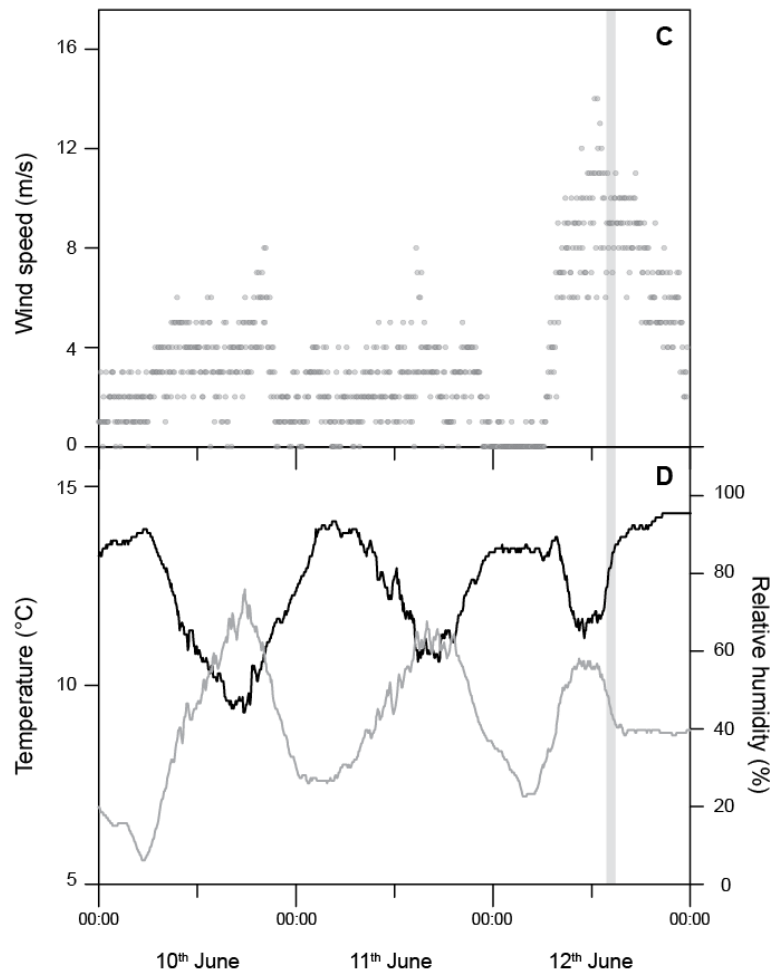

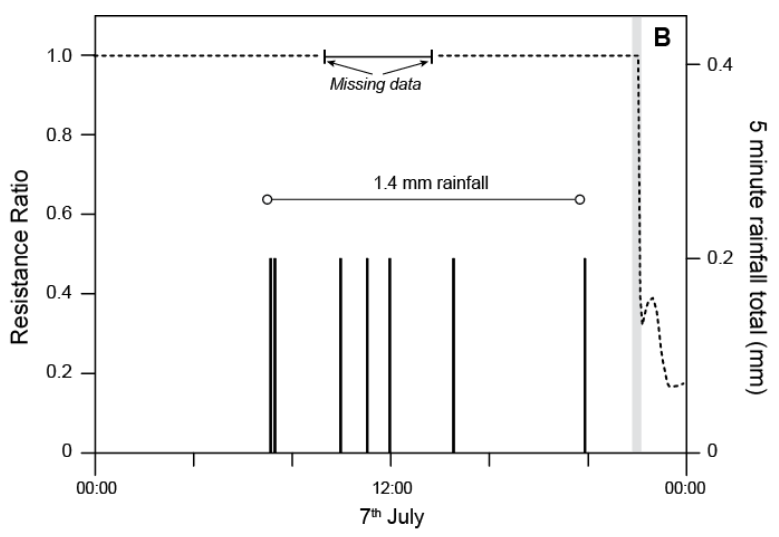

5 minute rainfall total $(\mathrm{mm})$

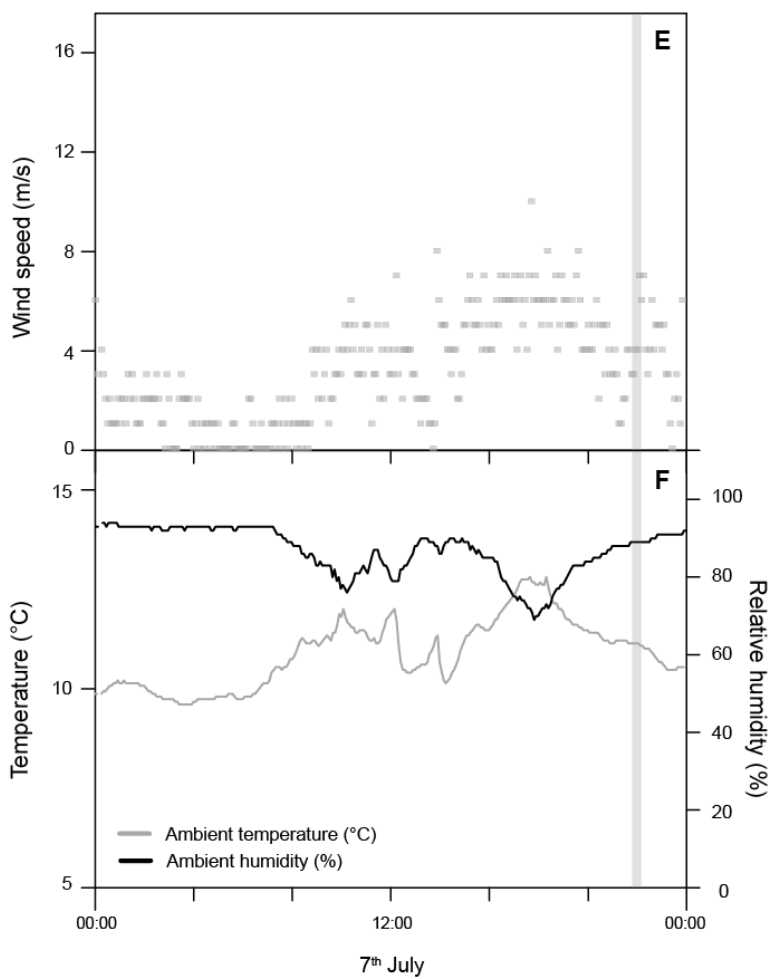


Figure 11: Detail of the drying sequence as recorded at depths of 5, 10, 20 and $50 \mathrm{~mm}$ below the surface of the northeast-facing block following a rainfall event. The relative 'time of wetness' is also shown as a percentage of the 17-day period.

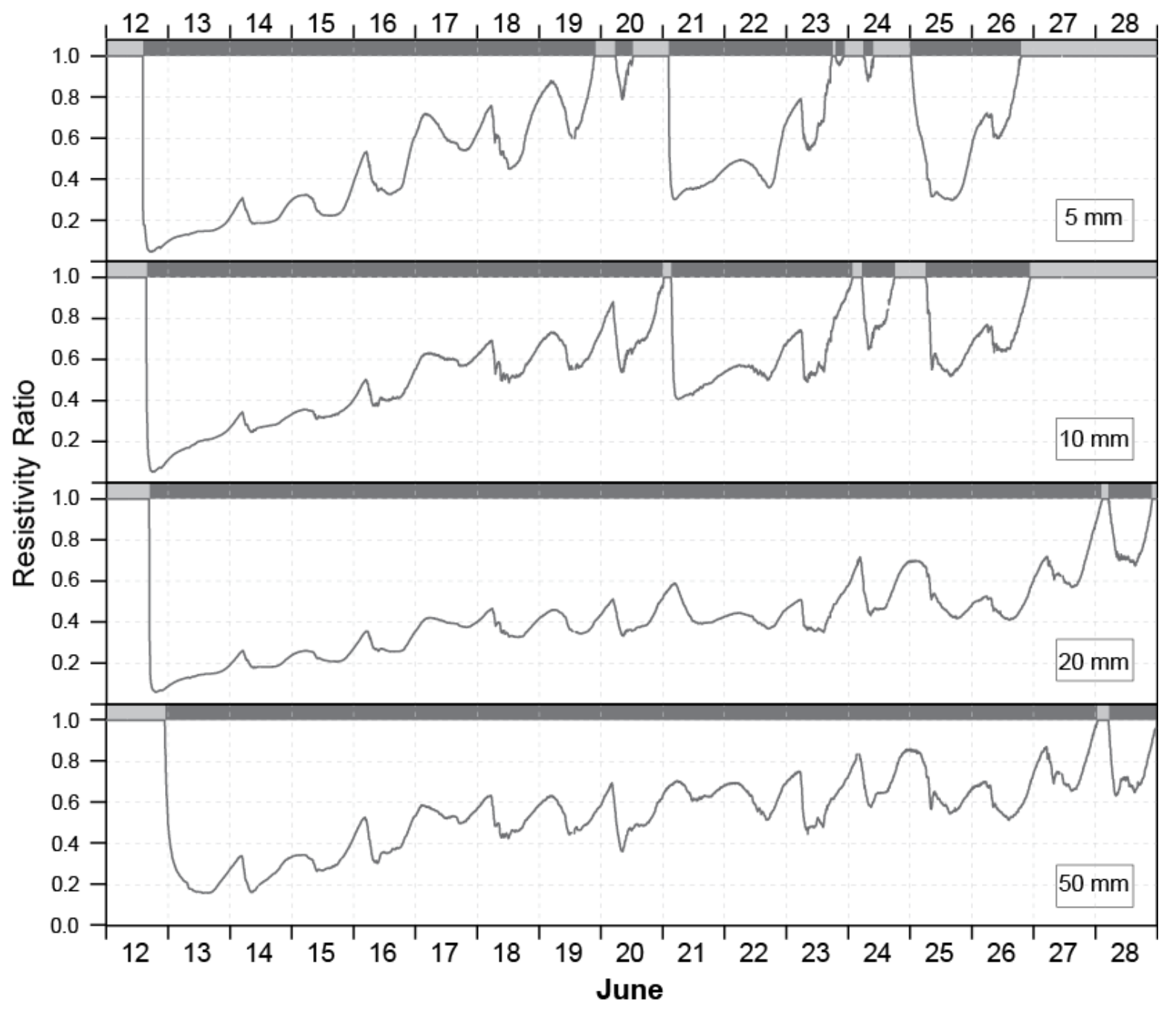

\begin{tabular}{|c|c|c|c|c|c|c|c|}
\hline \multirow[t]{2}{*}{ Dry (1.0) } & \multicolumn{2}{|c|}{ Stone moisture condition } & \multicolumn{5}{|c|}{ Percentage time spent under wet/dry conditions } \\
\hline & & & Dry & $\begin{array}{l}5 \mathrm{~mm} \\
27.3 \%\end{array}$ & $\begin{array}{l}10 \mathrm{~mm} \\
20.1 \%\end{array}$ & $\begin{array}{r}20 \mathrm{~mm} \\
5.0 \%\end{array}$ & $\begin{array}{r}50 \mathrm{~mm} \\
6.6 \%\end{array}$ \\
\hline Vet $(0.0)$ & Wet & Dry & Wet & $72.7 \%$ & $79.9 \%$ & $95.0 \%$ & $93.4 \%$ \\
\hline
\end{tabular}


Figure 12: Conceptual model of the development of differences in thermal response characteristics between stone exposed to different aspects and between the near-surface and deeper fabric of stone.

(a) Southwest-facing aspect (day time)

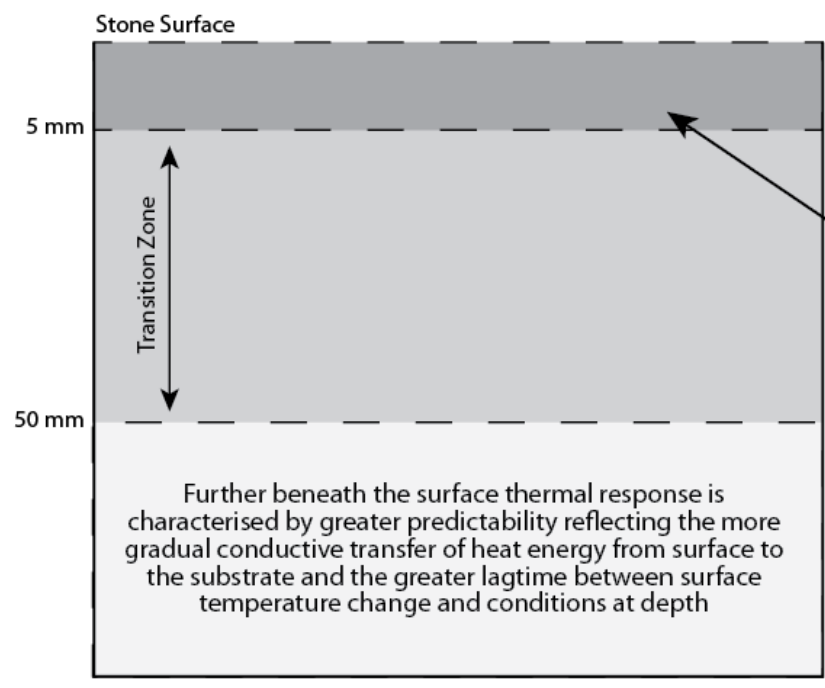

(Not to Scale)

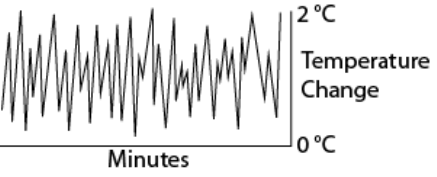

Outer few millimeters characterised by an unpredictable and energetic thermal response driven by increased energy inputs from direct radiative heating and factors such as the passage of cloud that temporarily interrupts this and turbulent airflow that carries heat away from the stone surface

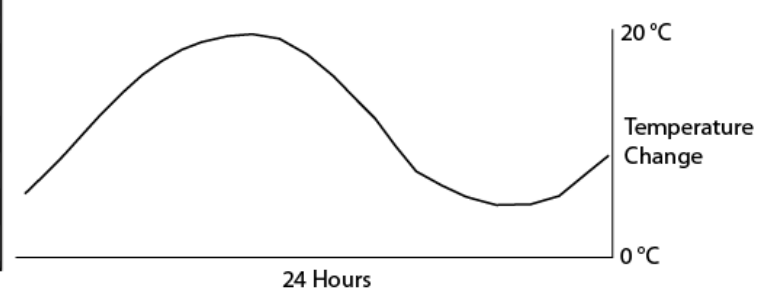

(b) Northeast-facing aspect (day time)

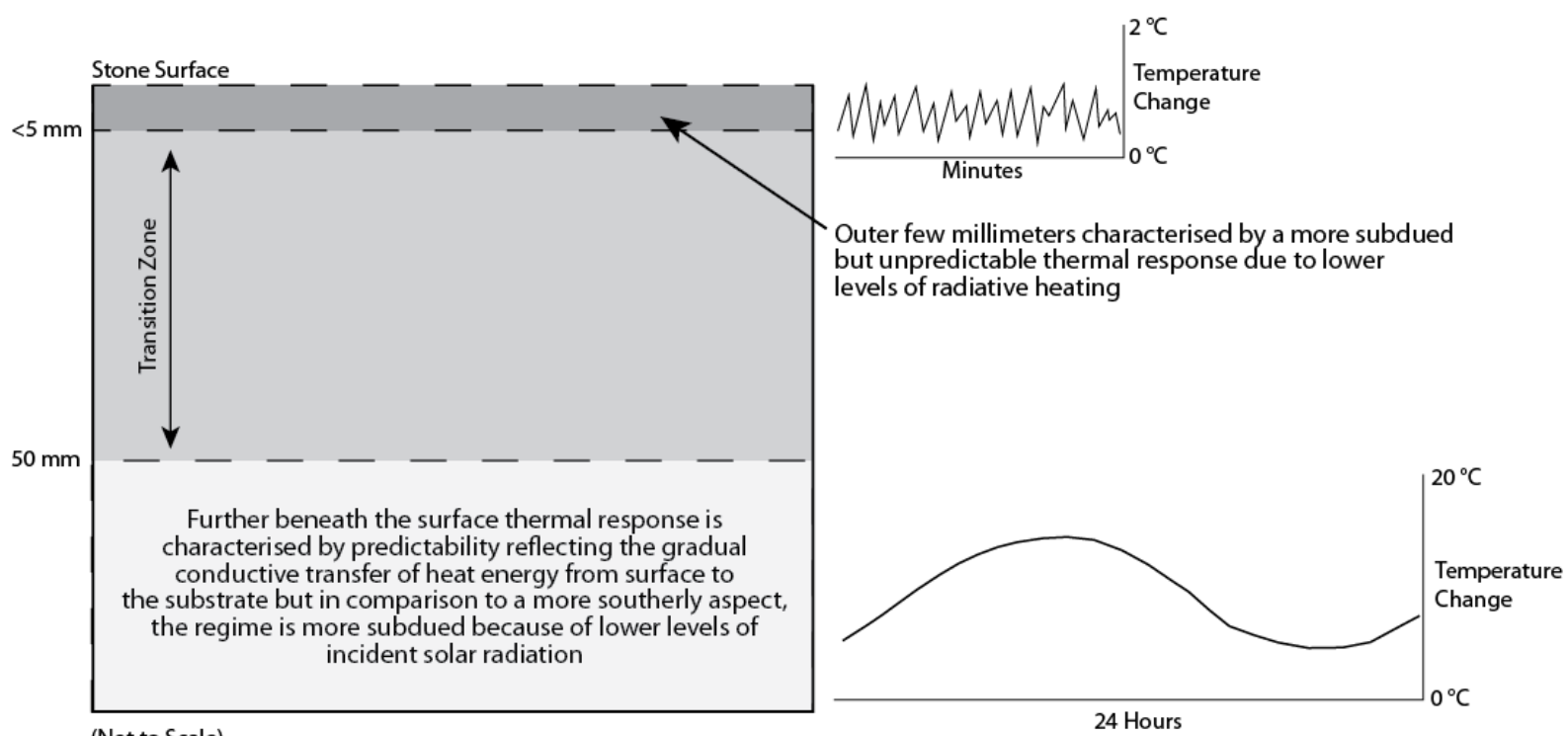

(Not to Scale) 